Review

\title{
Omega-3 Fatty Acids and Neurodegenerative Diseases: New Evidence in Clinical Trials
}

\author{
Rossella Avallone ${ }^{1, *}$, Giovanni Vitale ${ }^{1}$ and Marco Bertolotti ${ }^{2}$ (D) \\ 1 Department of Life Sciences, Modena and Reggio Emilia University, 41125 Modena, Italy \\ 2 Division of Geriatric Medicine, Department of Biomedical, Metabolic and Neural Sciences, and Center for \\ Gerontological Evaluation and Research, Modena and Reggio Emilia University, 41126 Modena, Italy \\ * Correspondence: rossella.avallone@unimore.it; Tel.: +39-059-2055720
}

Received: 24 July 2019; Accepted: 28 August 2019; Published: 30 August 2019

\begin{abstract}
A nutritional approach could be a promising strategy to prevent or slow the progression of neurodegenerative diseases such as Parkinson's and Alzheimer's disease, since there is no effective therapy for these diseases so far. The beneficial effects of omega-3 fatty acids are now well established by a plethora of studies through their involvement in multiple biochemical functions, including synthesis of anti-inflammatory mediators, cell membrane fluidity, intracellular signaling, and gene expression. This systematic review will consider epidemiological studies and clinical trials that assessed the impact of supplementation or dietary intake of omega-3 polyunsaturated fatty acids on neurodegenerative diseases such as Parkinson's and Alzheimer's diseases. Indeed, treatment with omega-3 fatty acids, being safe and well tolerated, represents a valuable and biologically plausible tool in the management of neurodegenerative diseases in their early stages.
\end{abstract}

Keywords: omega-3 polyunsaturated fatty acids; Parkinson's disease; Alzheimer's disease; clinical trials

\section{Introduction}

Several cerebral functions are determined by some nutrients, such as omega-3 polyunsaturated fatty acids (PUFAs), which are parts of the plasma membrane implicated in several processes, including increased synaptic development and functionality [1], effects on synaptic integrity and plasticity [2-5], contributing to neuroplasticity and subsequent enhancement of cognitive activity [6].

There is accumulating scientific evidence on the possible efficacy of PUFAs supplementation in neurodegenerative disorders [7,8], such as Parkinson's (PD) and Alzheimer's disease (AD) [9-13]. Although dietary recommendations are far from being a treatment for PD or AD, they may be able to alleviate some of the symptoms or slow the cognitive and physical decline.

The present study systematically reviews the effects of omega-3 polyunsaturated fatty acids ${ }^{\prime}$ supplementation on cognitive function in patients with Parkinson's or Alzheimer's disease.

The main classes of PUFAs belong to the omega- 3 one, which comprises $\alpha$-linolenic acid (ALA, 18:3 $\omega-3$ ), eicosapentaenoic acid (EPA, 20:5 $\omega-3)$ and docosahexaenoic acid (DHA, 22:6 $\omega-3)$ and to the omega-6 one, which comprises linoleic acid (LA, 18:2 $\omega-6$ ) and arachidonic acid (ARA, 20:4 $\omega-6$ ) [14] (Table 1). DHA and ARA are the most important PUFAs in the brain [15]. In particular, DHA constitutes over $90 \%$ of the $\omega-3$ PUFAs and $10-20 \%$ of total lipids in the brain [16]. It is mainly incorporated in phosphatidylethanolamine, phosphatidylserine and in smaller amounts in phosphatidylcholine [17] at synaptic terminals, mitochondria and endoplasmic reticula. Indeed, DHA is able to modulate cellular properties and physiological processes such as membrane fluidity, release of neurotransmitters, gene expression, myelination, neuroinflammation and neuronal growth $[18,19]$.

DHA results from ALA, while ARA from LA by desaturation and elongation of the carbon chain [20] (Figure 1). Humans can synthesize saturated and monounsaturated fatty acids (MUFAs), 
but they are not able to synthesize ALA and LA due to the deficiency of the conversion enzyme $\omega$-3-desaturase [21]. LA and ALA request the same conversion enzymes, consequently there is competitive inhibition between the two substrates. Delta-6-desaturase promotes the conversion of omega- 3 fatty acids into omega- 6 fatty acids. However, an increased LA intake may shift the balance towards the conversion of omega-6 PUFA thus inhibiting the conversion of ALA to DHA [22].

Table 1. Fatty acids' categories.

\begin{tabular}{cccc}
\hline \multirow{4}{*}{ Fatty Acids } \\
\hline & \multicolumn{3}{c}{ Unsaturated } \\
\hline & MUFA & \multicolumn{2}{c}{ PUFA } \\
\hline & omega-9 & omega-3 & omega-6 \\
\hline \multirow{3}{*}{ stearic acid 18:0 } & oleic acid 18:1 & ALA 18:3 & LA 18:2 \\
& & EPA 20:5 & ARA 20:4 \\
\hline
\end{tabular}

Esterified DHA in food, is released by the intestinal lipases in free unesterified form (DHA-FFA) in the small intestine and, after intestinal and hepatic metabolism, it can be found esterified in triglycerides and in phosphotidylcholine or as free DHA linked to low-density lipoprotein or albumin [15]. Endothelial lipases, fatty acid-binding proteins (FABP) and apolipoprotein E (ApoE) [23-26] dissociate the different forms in the blood-brain barrier (BBB) with both active and passive mechanisms [27]. The DHA, via FABP $[24,25]$ and ApoE produced by astrocytes, [26] is transported within the central nervous system.

DHA is incorporated into membrane phospholipids mainly in the stereospecifically numbered-2 position through the action of coenzyme A [28]. However, through hydrolysis reactions catalyzed by phospholipase, DHA can be released from membrane phospholipids. Both synthesis and hydrolysis represent mechanisms aimed at responding to dynamic cellular events and challenges during development and aging [14].

DHA, EPA, and ARA are also important for the production of eicosanoids (prostaglandins, thromboxanes, leukotrienes) and, therefore, for their involvement in inflammation [20]. The phospholipase A2 enzymes (PLA2) hydrolyze the phospholipid by releasing fatty acids. As a result of an inflammatory stimulus involving specific cell activation, therefore, there is an increase in the levels of free fatty acids. Three types of PLA2 are mainly implicated in the release of bioactive lipids: the cytosolic calcium-dependent PLA2 (cPLA2), the cytosolic calcium-independent PLA2 (iPLA2) and the secretory PLA2 (sPLA2) [29]. Among them, cPLA2, shows a substrate specificity for phospholipids containing arachidonic acid (AA). cPLA2, however, can also hydrolyze phospholipids containing EPA, but the low abundance of this fatty acid allows cPLA2 to release AA in specific conditions [30]. Inflammatory modulation is regulated by prostaglandins, leukotrienes, and thromboxanes, which are metabolized by cyclooxygenase (COX) and 5-lipoxygenase (5-LOX) [31]. ARA is antecedent to the 2-series prostaglandins, as well as to thromboxanes and to 5-series leukotrienes [22]. Consequently, ARA has pro-inflammatory effects, while EPA has anti-inflammatory actions [22]. Furthermore, 5-LOX is responsible for the generation of anti-inflammatory eicosanoids such as the D-series resolvins, protectins and maresins, which are derived from DHA and the E-series resolvins from EPA [32,33] (Figure 1).

Human metabolic studies show a limited conversion of ALA to DHA, typically below $5 \%$ in adult males [34-37]. Women have a greater efficiency of conversion than men [38] and this may be important for fetal supply during pregnancy. Women demonstrated lower omega-3 fatty acid intake than men considering the same age categories [39]. Moreover, delta- 6 desaturase activity decreases with age and undergoes lesser conversion, mainly in women. Therefore, to get the sufficient intake of EPA and DHA, especially in aging dietary supplements containing these preformed omega- 3 are necessary. 
Indeed, the shift in modern diets towards reduced omega-3 PUFA intake increases omega-6 PUFA consumption and, if combined with less physical activity, has a detrimental impact on development and aging, especially with regard to cognitive function [14].

Current guidelines suggest an intake of EPA and DHA within the range of 250 to $500 \mathrm{mg}$ [40]. As indicated by modern daily dietary, the consumption of omega-3 PUFAs is lower than necessary. DHA intakes, indeed, are closer to $100 \mathrm{mg}$ per day, the optimal dietary omega- 6 to omega- 3 PUFA ratio has been determined in 2:1 or lesser, whereas the Western diet is usually established in the range of 10:1 to $25: 1$ [14].

The DHA daily dose necessary to induce significant positive results still requires further research. For example, a portion of $135 \mathrm{~g}$ of Atlantic salmon is necessary to reach $2 \mathrm{~g} /$ die of DHA [41] (Table 2). Thus, it is very difficult to achieve such high DHA consumption without integrations [7].

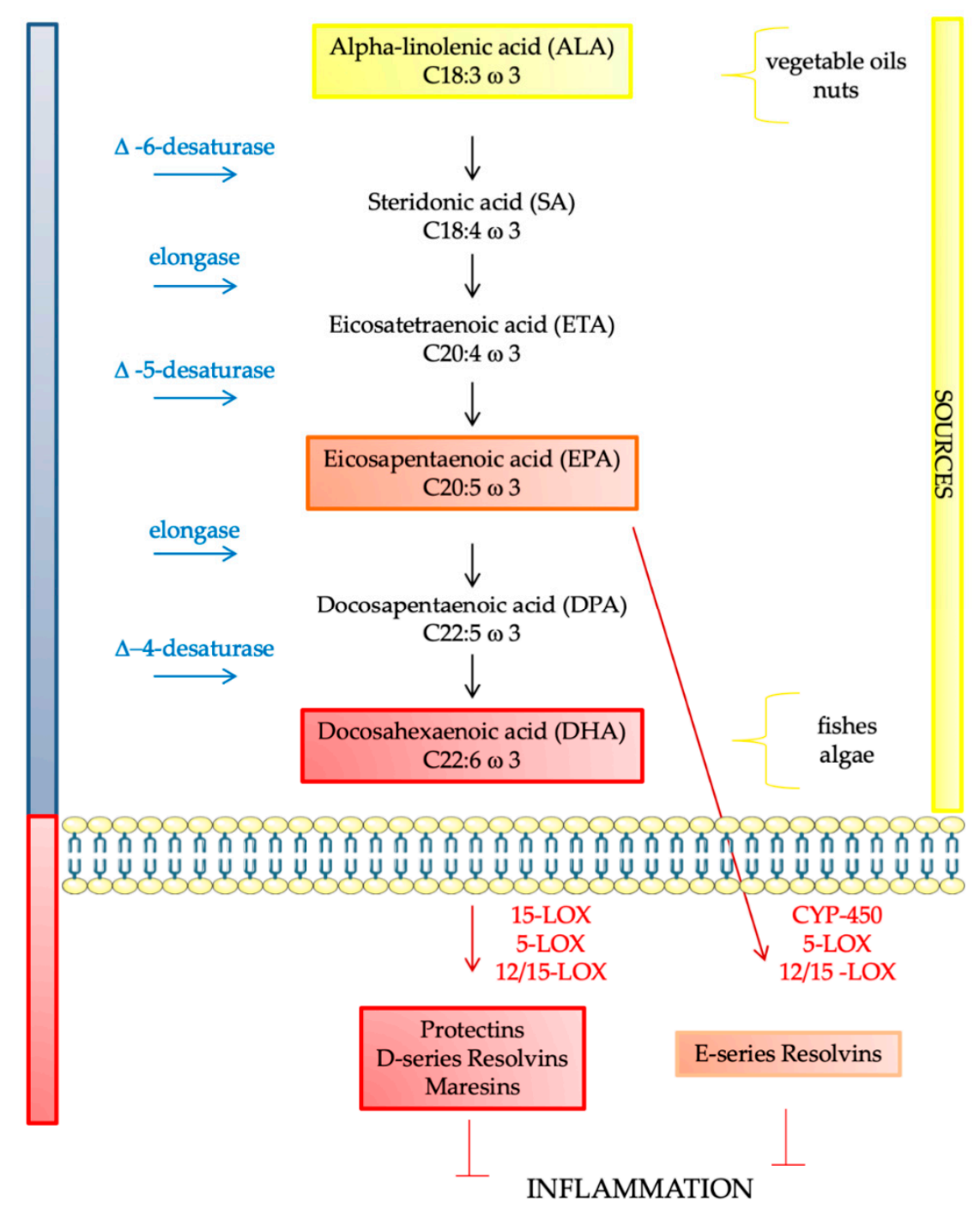

Figure 1. Endogenous synthesis of omega-3 polyunsaturated fatty acids and their involvement in inflammation. 15-LOX: 15-Lipoxygenase, 5-LOX: 5-Lipoxygenase, 12/15-LOX: 12/15 Lipoxygenase, CYP-450: Cytochrome P450. 
Table 2. Amount of $\alpha$-linolenic acid (ALA), eicosapentaenoic acid (EPA), and docosahexaenoic acid (DHA).

\begin{tabular}{|c|c|c|c|}
\hline Food & ALA g/Portion & EPA g/Portion & DHA g/Portion \\
\hline Baked beans, canned, vegetarian & 0.07 & & \\
\hline Black walnuts & 0.76 & & \\
\hline Bread, whole wheat & 0.04 & & \\
\hline Canola oil & 1.28 & & \\
\hline Chia seeds & 5.06 & & \\
\hline Chicken, breast, roasted, & & 0.01 & 0.02 \\
\hline Cod, Pacific, cooked ${ }^{*}$ & & 0.04 & 0.10 \\
\hline Edamame, frozen, prepared & 0.28 & & \\
\hline Egg, cooked & & & 0.03 \\
\hline English walnuts & 2.57 & & \\
\hline Flaxseed oil & 7.26 & & \\
\hline Flaxseed, whole & 2.35 & & \\
\hline Ground beef, $85 \%$ lean, cooked ** & 0.04 & & \\
\hline Herring, Atlantic, cooked * & & 0.77 & 0.94 \\
\hline Kidney beans, canned & 0.10 & & \\
\hline Lobster, cooked * & 0.04 & 0.10 & 0.07 \\
\hline Mackerel, Atlantic, cooked * & & 0.43 & 0.59 \\
\hline Mayonnaise & 0.74 & & \\
\hline Milk, low-fat (1\%) & 0.01 & & \\
\hline Oysters, eastern, wild, cooked & 0.14 & 0.30 & 0.23 \\
\hline Refried beans, canned, vegetarian & 0.21 & & \\
\hline Salmon, Atlantic, farmed, cooked & & 0.59 & 1.24 \\
\hline Salmon, Atlantic, wild, cooked & & 0.35 & 1.22 \\
\hline Salmon, pink, canned, drained * & 0.04 & 0.28 & 0.63 \\
\hline $\begin{array}{c}\text { Sardines, canned in tomato sauce, } \\
\text { drained * }\end{array}$ & & 0.45 & 0.74 \\
\hline Scallops, cooked ${ }^{*}$ & & 0.06 & 0.09 \\
\hline Sea bass, cooked * & & 0.18 & 0.47 \\
\hline Shrimp, cooked * & & 0.12 & 0.12 \\
\hline Soybean oil & 0.92 & & \\
\hline Tilapia, cooked * & 0.04 & & 0.11 \\
\hline Trout, rainbow, wild, cooked & & 0.40 & 0.44 \\
\hline Tuna, light, canned in water, drained * & & 0.02 & 0.17 \\
\hline Tuna, yellowfin, cooked $*$ & & 0.01 & 0.09 \\
\hline
\end{tabular}

* Except as noted, the USDA database does not specify whether fish are farmed or wild-caught. ${ }^{* *}$ The United States Department of Agriculture Food Composition Databases does not specify whether beef is grass-fed or grain-fed. Data from Office of Dietary Supplements, National Institute of Health (NIH) [42,43].

\section{Parkinson's Disease}

Parkinson's disease is a progressive neurodegenerative disorder characterized by loss of dopaminergic neurons in the substantia nigra, pars compacta. A pathological hallmark of the disease is also the presence of Lewy bodies, which are intracellular inclusions enriched in the protein $\alpha$-synuclein.

The common symptoms include tremor, rigidity, bradykinesia and postural insecurity, with dementia and depression observed in the advanced stages of the disease [29]. In many instances, depression occurs before motor symptoms, which are typical expressions of Parkinson's classic onset. In a recent study, it has also been shown that people suffering from depression are three-fold more predisposed to develop PD [44]. Depression, which affects a third of PD patients, combined with anxiety, apathy, and anhedonia further renders the PD outcomes even more complicated [29].

Although the etiology is currently unknown, there are a number of putative risk factors (e.g., exposure to environmental toxins) [45] and the pathogenic mechanisms include mitochondrial dysfunction, neuroinflammation, and oxidative stress [46]. However, numerous studies support that a diet rich in PUFAs or supplementation with food products containing EPA and DHA could alleviate some of the patients' symptoms. The main scales used to evaluate PD symptoms are summarized in Table 3. 
Table 3. Summary of main scales used for assessment of Parkinson's and Alzheimer's Disease ([47] with modifications).

\begin{tabular}{|c|c|}
\hline Main Scales & Description \\
\hline $\begin{array}{l}\text { Activities of Daily Living } \\
\text { ADCS-ADL, ADCS-IADL }\end{array}$ & $\begin{array}{l}\text { It measures the functional ability to perform activities of daily life. ADL } \\
\text { assess basic living skills such as bathing and eating, whereas Instrumental } \\
\text { activities of daily living (IADL) measures more complex tasks such as } \\
\text { using the telephone or preparing meals. A higher ADL or IADL score } \\
\text { indicates a worsening functionality. }\end{array}$ \\
\hline $\begin{array}{l}\text { Alzheimer's Disease } \\
\text { Assessment Scale-Cognitive } \\
\text { Subscale (ADAS-Cog) }\end{array}$ & $\begin{array}{l}\text { It is a sensitive and reliable method for the assessment of cognitive } \\
\text { function in dementia. It consists of a psychometric scale of } 11 \text { items, and } \\
\text { scores range from } 0 \text { (no impairment) to } 70 \text { (very severe impairment). }\end{array}$ \\
\hline $\begin{array}{l}\text { Beck Depression Inventory } \\
\text { (BDI) }\end{array}$ & $\begin{array}{l}\text { It is a } 21 \text {-question multiple-choice self-report inventory, one of the most } \\
\text { widely used psychometric tests for measuring the severity of depression. }\end{array}$ \\
\hline $\begin{array}{l}\text { Brief Assessment Schedule } \\
\text { Depression Cards (BASDEC) }\end{array}$ & $\begin{array}{l}\text { It is a brief test for screening depression, requiring minimal training to } \\
\text { administer. }\end{array}$ \\
\hline $\begin{array}{l}\text { Bristol's Activities of Daily } \\
\text { Living Scale (BADLS) }\end{array}$ & $\begin{array}{l}\text { It is specifically designed for individuals with mild dementia living in the } \\
\text { community for completion by caregivers. }\end{array}$ \\
\hline $\begin{array}{l}\text { Clinical Dementia Rating } \\
\text { (CDR) }\end{array}$ & $\begin{array}{l}\text { It is a global measure that assesses memory, orientation, judgment, and } \\
\text { other features. Is based on caregiver interview. Classifies dementia into } \\
\text { questionable, mild, moderate, and severe. }\end{array}$ \\
\hline $\begin{array}{l}\text { Clinical Global Impression } \\
\text { Scale (CGI) }\end{array}$ & $\begin{array}{l}\text { It measures symptom severity, treatment response, and the efficacy of } \\
\text { treatments in treatment studies of patients with mental disorders. }\end{array}$ \\
\hline $\begin{array}{l}\text { Clinician Interview-Based } \\
\text { Impression of Change, plus } \\
\text { carer interview (CIBIC-Plus) }\end{array}$ & $\begin{array}{l}\text { It is a global measure capable of detecting changes in cognition, } \\
\text { functionality, and behavior, thus assessing dementia's severity and } \\
\text { progression. Requires separate interviews with patients and caregivers. }\end{array}$ \\
\hline $\begin{array}{l}\text { Diagnostic and Statistical } \\
\text { Manual of Mental Disorders, } \\
\text { fourth edition (DSM-IV) }\end{array}$ & $\begin{array}{l}\text { It is the handbook used by health care professionals in the United States } \\
\text { and much of the world as the authoritative guide to the diagnosis of } \\
\text { mental disorders. }\end{array}$ \\
\hline $\begin{array}{l}\text { Hamilton Depression Rating } \\
\text { Scale (HDRS) }\end{array}$ & $\begin{array}{l}\text { Is the most widely used clinician-administered depression assessment } \\
\text { scale. The original version contains } 17 \text { items pertaining to symptoms of } \\
\text { depression experienced over the past week. }\end{array}$ \\
\hline Hoehn and Yahr scale & $\begin{array}{l}\text { It is a commonly used system for describing how the symptoms of PD } \\
\text { progress. }\end{array}$ \\
\hline $\begin{array}{l}\text { Hopkins Verbal Learning } \\
\text { Test-Revised (HVLT-R) }\end{array}$ & $\begin{array}{l}\text { It is a brief verbal learning and memory test ideal in situations calling for } \\
\text { repeated neuropsychological examinations. }\end{array}$ \\
\hline $\begin{array}{l}\text { Mini-Mental State Examination } \\
\text { (MMSE) }\end{array}$ & $\begin{array}{c}\text { It evaluates cognitive function in the areas of orientation, memory, } \\
\text { attention, calculation, language, and visual construction. It is widely } \\
\text { translated and used in clinical practice. Patients score between } 0 \text { and } 30 \\
\text { points, and cutoffs of } 23 / 24 \text { have typically been used to show significant } \\
\text { cognitive impairment. }\end{array}$ \\
\hline $\begin{array}{l}\text { Montgomery-Åsberg } \\
\text { Depression Rating Scale } \\
\text { (MADRS) }\end{array}$ & $\begin{array}{l}\text { It is a ten-item diagnostic questionnaire which psychiatrists use to measure } \\
\text { the severity of depressive episodes in patients with mood disorders. }\end{array}$ \\
\hline $\begin{array}{l}\text { Neuropsychiatric Inventory } \\
\text { (NPI) }\end{array}$ & $\begin{array}{l}\text { It assesses dementia-related behavioral symptoms. The NPI originally } \\
\text { examined } 10 \text { sub-domains of behavioral functioning: Delusions, } \\
\text { hallucinations, agitation/aggression, dysphoria, anxiety, euphoria, apathy, } \\
\text { disinhibition, irritability/lability, and aberrant motor activity. }\end{array}$ \\
\hline $\begin{array}{l}\text { Neuropsychological test } \\
\text { battery (NTB) }\end{array}$ & $\begin{array}{l}\text { This scale assesses changes in cognitive function and is seen as a } \\
\text { promising method for mild AD. NTB has shown to be able to detect } \\
\text { changes in memory performance. }\end{array}$ \\
\hline $\begin{array}{l}\text { Unified Parkinson's Disease } \\
\text { Rating Scale (UPDRS) }\end{array}$ & It evaluates motor impairment and disability of patients with PD. \\
\hline
\end{tabular}




\subsection{The Role of Omega-3 Polyunsaturated Fatty Acids in PD: Observational Studies}

The first major prospective study concerning environmental, lifestyle, and physical precursors of clinical Parkinson's disease is the Honolulu-Asia Aging Study [48], which started in 1965 and included a cohort of 8006 Japanese-American men, during a 30-year follow-up. Among the dietary factors showing an inverse association with PD, the polyunsaturated fats [48] were included (Table 4).

Table 4. Prospective observational studies assessing the impact of omega-3 fatty acids supplementation in Parkinson's disease PD patients.

\begin{tabular}{|c|c|c|c|c|c|}
\hline $\mathbf{N}^{\circ}$ Patients & $\begin{array}{l}\text { Population } \\
\text { Characteristic }\end{array}$ & $\begin{array}{l}\text { Type and Dose } \\
\text { Supplementation }\end{array}$ & $\begin{array}{l}\text { Exposure } \\
\text { Period }\end{array}$ & Results & References \\
\hline 8006 & $\begin{array}{c}\text { PD } \\
\text { Honolulu-Asia } \\
\text { Aging Study }\end{array}$ & $\begin{array}{l}\text { Food frequency } \\
\text { questionnaire }\end{array}$ & 30 years & $\begin{array}{c}\text { Omega-3 PUFAs } \\
\text { appeared } \\
\text { protective. }\end{array}$ & [48] \\
\hline 5289 & $\begin{array}{l}\text { PD Rotterdam } \\
\text { Study The } \\
\text { Netherlands }\end{array}$ & $\begin{array}{l}\text { Semiquantitative } \\
\text { food frequency } \\
\text { questionnaire }\end{array}$ & 6 years & $\begin{array}{l}\text { Intakes of omega-3 } \\
\text { PUFAs were } \\
\text { significantly } \\
\text { associated with a } \\
\text { lower risk of PD. }\end{array}$ & [49] \\
\hline 131,368 & $\begin{array}{l}\text { PD Health } \\
\text { Professionals } \\
\text { Follow-Up } \\
\text { Study and the } \\
\text { Nurses' Health } \\
\text { Study USA }\end{array}$ & $\begin{array}{l}\text { Semiquantitative } \\
\text { food frequency } \\
\text { questionnaire }\end{array}$ & 16 years & $\begin{array}{l}\text { High intakes of } \\
\text { fruit, vegetables, } \\
\text { whole grains, } \\
\text { legumes, poultry, } \\
\text { and fish were } \\
\text { associated with a } \\
\text { lower risk of PD. }\end{array}$ & {$[50]$} \\
\hline 249 & PD Japan & $\begin{array}{l}\text { Self-administered } \\
\text { diet history } \\
\text { questionnaire }\end{array}$ & 6 years & $\begin{array}{c}\text { Consumption of } \\
\text { omega-3 PUFA, } \\
\text { ALA, EPA, DHA } \\
\text { was not associated } \\
\text { with PD. }\end{array}$ & [51] \\
\hline
\end{tabular}

In The Rotterdam Study, the intakes of total fats, MUFAs and PUFAs were significantly associated with a lower risk of PD, by means of energy-adjusted intake of fat and fatty acids [49].

The association between dietary lifestyle and the risk of PD was evaluated in two most important studies: The Health Professionals Follow-Up Study (1986-2002) and the Nurses' Health Study (1984-2000), including 131,368 men and women. Two dietary styles have been identified and compared: Prudent diet, characterized by high consumption of fruit, vegetables and fish and Western diet. It was demonstrated that the prudent diet significantly reduced PD risk, while the Western diet did not [50].

However, a case-control study, which examined the relationship between dietary intake of individual fatty acids and the risk of PD in Japan, including 249 cases within six years of onset of PD, demonstrated that, if the higher consumption of ARA and cholesterol could be related to an increased risk of $\mathrm{PD}$, the intake of omega-3 polyunsaturated fatty acids was not [51].

In summary, we can conclude that prospective observational studies showed an association between a diet rich in polyunsaturated omega-3 fatty acids with a lower risk of PD.

\subsection{The Role of Omega-3 Polyunsaturated Fatty Acids in PD: Randomized, Double-Blind, Placebo-Controlled Clinical Trials}

Randomized, double-blind, placebo-controlled clinical trials involving PD are few for several reasons: poor patient adherence to diet therapy, duration of dietary treatment, control of clinical parameters and evaluation of these same parameters. When the pathology occurs, already $70 \%$ of neurons are compromised. Thus, thinking that only a dietary treatment can restore brain functions is really a utopia. However, dietary treatments with omega-3 fatty acids may have advantages in reducing inflammation and, consequently, depressive symptoms. 
Indeed, treatment for six months with $800 \mathrm{mg} /$ day DHA and $290 \mathrm{mg} /$ day EPA from fish oil, demonstrated, in the DHA-treated patients, a reduction of $50 \%$ in the Hamilton rating scale for depression (HDRS) total score if compared with the placebo group which took corn oil. DHA integration reduced depressive symptoms [52]. However, treatment had no statistically significant effect on the rate of change on either unified Parkinson's disease rating scale (UPDRS) or Hoehn-Yahr scale score [52] (Table 5).

Table 5. Clinical trials assessing the impact of omega-3 fatty acids supplementation in PD patients.

\begin{tabular}{|c|c|c|c|c|c|}
\hline $\mathbf{N}^{\circ}$ Patients & $\begin{array}{l}\text { Population } \\
\text { Characteristics }\end{array}$ & $\begin{array}{l}\text { Type and Dose } \\
\text { Supplementation }\end{array}$ & $\begin{array}{c}\text { Exposure } \\
\text { Period }\end{array}$ & Results & References \\
\hline 24 & PD Italy & $\begin{array}{l}800 \mathrm{mg} / \text { die DHA } \\
+290 \mathrm{mg} / \text { die EPA } \\
\text { from fish oil } \\
\text { Placebo: Corn oil }\end{array}$ & 6 months & $\begin{array}{l}\text { Treatment had no } \\
\text { statistically } \\
\text { significant effect on } \\
\text { the rate of change } \\
\text { on either UPDRS or } \\
\text { Hoehn-Yahr Scale } \\
\text { score. In } \\
\text { DHA-treated } \\
\text { patients, the HDRS } \\
\text { score was reduced } \\
\text { by at least } 50 \% .\end{array}$ & [52] \\
\hline 31 & $\begin{array}{l}\text { PD and Major } \\
\text { Depression } \\
\text { (DSM-IV) Brazil }\end{array}$ & $\begin{array}{c}480 \mathrm{mg} / \text { die DHA } \\
+720 \mathrm{mg} / \text { die EPA } \\
\text { from fish oil + } \\
\text { tocopherol } \\
\text { Placebo: Mineral } \\
\text { oil }\end{array}$ & 3 months & $\begin{array}{l}\text { Treatment had no } \\
\text { statistically } \\
\text { significant effect on } \\
\text { the rate of change } \\
\text { on Hoehn-Yahr } \\
\text { Scale score, but } \\
\text { there was a } \\
\text { significant decrease } \\
\text { in MADRS and } \\
\text { CGI scores. }\end{array}$ & [44] \\
\hline 60 & PD Iran & $\begin{array}{l}1000 \text { mg omega-3 } \\
\text { fatty acids from } \\
\text { flaxseed oil + } 400 \\
\text { IU vitamin E } \\
\text { Placebo: Not } \\
\text { specified }\end{array}$ & 3 months & $\begin{array}{l}\text { Treatment had } \\
\text { favorable effects on } \\
\text { UPDRS score. }\end{array}$ & [53] \\
\hline
\end{tabular}

Another double-blind, placebo-controlled study analyzed the effect of fish oil supplementation in parkinsonian patients with depression measured using Montgomery-Asberg rating scale (MADRS), the clinical global impressions scale (CGI) and Beck depression inventory (BDI) [44]. After three months, the supplementation with four capsules of omega-3 from fish oil (each capsule containing $180 \mathrm{mg}$ EPA, $120 \mathrm{mg}$ DHA and tocopherol) showed a significant decrease in MADRS and CGI-depression scores while there was no difference among treated and control groups in BDI [44]. Moreover, Parkinson's symptoms, measured by Hoehn and Yahr scale, did not show significant variation during the three months of supplementation in all groups observed [44].

A randomized double-blind placebo-controlled clinical trial, conducted in 60 patients with PD, receiving either $1000 \mathrm{mg}$ omega-3 fatty acids from flaxseed oil plus $400 \mathrm{IU}$ vitamin E supplements or placebo for three months, showed that the dietetic supplementation in people with PD improved UPDRS, compared with the placebo [53].

The published papers give an important indication on the use of omega- 3 supplements, especially for depression in PD. However, the number of patients recruited is small and also the types of supplements vary. It is widely demonstrated that the effective dose is $1 \mathrm{~g} /$ day of DHA. Animal or algal sources ensure a correct intake of DHA, while plant sources are often ineffective, since only $10 \%$ of ALA is metabolized to DHA. Despite this, the supplementation of omega-3 from linseed oil and vitamins 
E had favorable effects not only on UPDRS but also on high-sensitivity C-reactive protein (hs-CRP), total antioxidant capacity (TAC), glutathione and markers of insulin metabolism [53]. Furthermore, the three-to-six-month treatment is a relatively short period considering that we deal with dietary intervention in a pathology where the main symptoms are already evident $[44,52,53]$.

\section{Alzheimer's Disease}

Alzheimer's Disease is a neurodegenerative syndrome that includes most cases of dementia, affecting over 35 million people all over the world. AD typical clinical features consist of cognitive impairment, memory loss, language disorders, rapid changes in mood and behavior, time- and space-disorientation, inhibition of the patients' daily habits. The neurodegenerative process observed in $\mathrm{AD}$ is usually present in patients' brain before the appearance of the first symptoms [54].

Neurofibrillary tangles, senile plaques, neuronal loss, and consequential brain atrophy represent the main features of AD.

Neurofibrillary tangles are formed by hyperphosphorylation and truncation of a protein, known as tau, which normally forms and stabilizes cytoskeleton by interaction with tubulin. As a result of the above-mentioned post-transcriptional modifications, tau protein can form toxic aggregates (i.e., neurofibrillary tangles) mainly situated in the hippocampus. Moreover, tau protein dysfunction produces cytoskeleton deconstruction as a result of microtubule disintegration, producing synaptic failure that produces a loss of communication and contributes to AD neurodegeneration.

Tau hyperphosphorylation also hinders mitochondrial transport since it is affected by interactions with microtubules, causing energy deficits in presynaptic areas that may result in a synaptic discontinuance.

The amyloid precursor protein (APP) degradation originates senile plaques constituted by extracellular deposits of $\beta$-amyloid peptide $(\mathrm{A} \beta)$ which induce inflammation and neuronal death. APP, a transmembrane protein present in neurons, can undergo cleavage by two different pathways: the amyloidogenic and the non-amyloidogenic ones, both mediated by secretases: $\beta$ - and $\gamma$-secretases are involved in the first one, while $\alpha$ - and $\gamma$-secretases in the second one (Figure 2) [54]. In the non-amyloidogenic pathway, APP is sequentially cleaved by $\alpha$-secretase and $\gamma$-secretase, generating truncation products: $A \beta_{17-40 / 42}$ peptides (Figure 2). In the amyloidogenic pathway, APP is sequentially cleaved by $\beta$-secretase and $\gamma$-secretase, leading to whole-length $A \beta$ peptides, responsible for the development of the plaques. While non-amyloidogenic pathway produces the amino-terminal fragment APPs $\alpha$ and the carboxy-terminal one C83, the amyloidogenic one produces APPs $\beta$ and C99. The activity of $\gamma$-secretase produces the APP intracellular domain (AICD), which takes part in the cellular signaling. Based on the point where $\gamma$-secretase generates the cut in the amyloidogenic pathway, the whole-length $A \beta$ peptide would undergo different reductions: $A \beta_{1-40}$ and $A \beta_{1-42}$ are the main brain fragments (Figure 2) [54]. In the amyloidogenic processing, DHA decreased the $\beta$ and $\gamma$-secretase activity, while in the non-amyloidogenic processing it increased ADAM17 protein level, caused by a decreased protein degradation and an increased expression level [55]. Moreover, DHA lowers amyloidogenic processing by modifying both $\beta$ - and $\gamma$-secretase activity with different mechanisms [55]. 

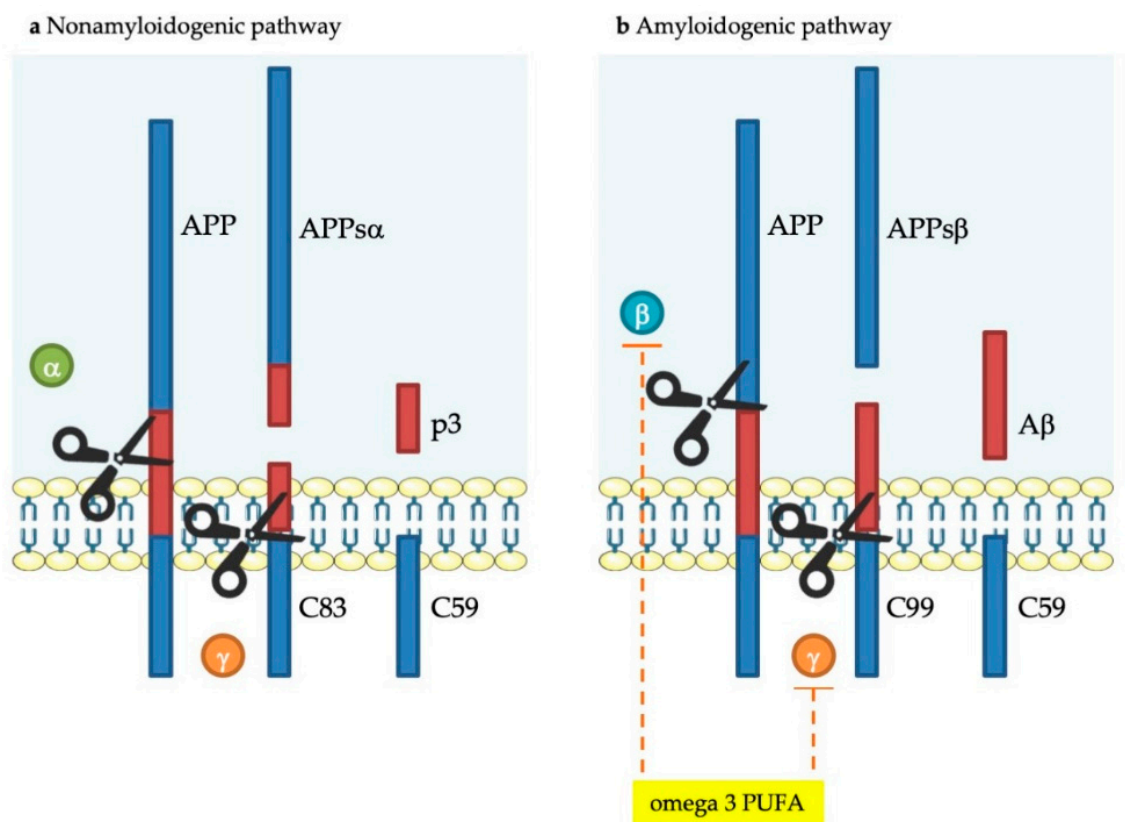

Figure 2. Amyloid precursor protein (APP) processing pathways. The non-amyloidogenic pathway (a) occurs upon sequential cleavage by $\alpha$-and $\gamma$-secretases (non-pathological situation). The amyloidogenic pathway route (b) occurs when cleavage is carried out sequentially by $\beta$ - and $\gamma$ secretases (pathological situation). Letters $\alpha, \beta$, and $\gamma$ represent each type of secretase. APP: Amyloid precursor protein, APPs $\alpha$ : Soluble $\alpha$-APP, APPs $\beta$ : Soluble $\beta$-APP. Omega- 3 polyunsaturated fatty acids, proposed to inhibit APP processing, are shown in orange dashed lines.

\subsection{The Role of Omega-3 Polyunsaturated Fatty Acids in AD: Observational Studies}

Prospective epidemiological studies performed in the Netherlands, USA, and France strongly supported a causal association between low fish and/or low DHA intake and AD. Most of the seven prospective studies published show that an increased intake of fish or omega-3 PUFA decreases the risk of AD (Table 6) [56].

Table 6. Prospective observational studies assessing the impact of omega-3 fatty acids supplementation in $\mathrm{AD}$ patients.

\begin{tabular}{|c|c|c|c|c|c|}
\hline $\mathbf{N}^{\circ}$ Patients & $\begin{array}{c}\text { Population } \\
\text { Characteristic }\end{array}$ & $\begin{array}{l}\text { Type and Dose } \\
\text { Supplementation }\end{array}$ & $\begin{array}{l}\text { Exposure } \\
\text { Period }\end{array}$ & Results & References \\
\hline 5386 & $\begin{array}{c}\text { AD } 37 \text { Rotterdam } \\
\text { Study The } \\
\text { Netherlands }\end{array}$ & $\begin{array}{l}\text { Semiquantitative } \\
\text { food frequency } \\
\text { questionnaire }\end{array}$ & 2.1 years & $\begin{array}{c}\text { Fish consumption, } \\
\text { an important source } \\
\text { of omega-3 PUFA, } \\
\text { was inversely related } \\
\text { to incident dementia, } \\
\text { in particular to } \\
\text { Alzheimer's disease. }\end{array}$ & [57] \\
\hline 815 & $\begin{array}{c}\text { AD 131 Chicago } \\
\text { Health and } \\
\text { Aging Project } \\
\text { USA }\end{array}$ & $\begin{array}{l}\text { Food frequency } \\
\text { questionnaire }\end{array}$ & 3.9 years & $\begin{array}{c}\text { Dietary intake of } \\
\text { omega-3 PUFA and } \\
\text { weakly consumption } \\
\text { of fish may reduce } \\
\text { the risk of } \\
\text { Alzheimer's disease. }\end{array}$ & [58] \\
\hline 2233 & $\begin{array}{c}\text { AD } 190 \\
\text { Cardiovascular } \\
\text { Health Cognition } \\
\text { Study (CHCS) } \\
\text { USA }\end{array}$ & $\begin{array}{l}\text { Food frequency } \\
\text { questionnaire }\end{array}$ & 5.4 years & $\begin{array}{l}\text { Consumption of fatty } \\
\text { fish more than twice } \\
\text { per week was } \\
\text { associated with a } \\
\text { reduction in the risk } \\
\text { of Alzheimer's } \\
\text { disease by } 41 \% \text {. }\end{array}$ & [59] \\
\hline
\end{tabular}


Table 6. Cont.

\begin{tabular}{|c|c|c|c|c|c|}
\hline $\mathbf{N}^{\circ}$ Patients & $\begin{array}{l}\text { Population } \\
\text { Characteristic }\end{array}$ & $\begin{array}{l}\text { Type and Dose } \\
\text { Supplementation }\end{array}$ & $\begin{array}{l}\text { Exposure } \\
\text { Period }\end{array}$ & Results & References \\
\hline 488 & $\begin{array}{l}\text { AD not reported } \\
\text { The Framingham } \\
\text { Heart Study USA }\end{array}$ & $\begin{array}{c}\text { Semiquantitative } \\
\text { food frequency } \\
\text { questionnaire }\end{array}$ & 9.1 years & $\begin{array}{l}\text { Plasma DHA level } \\
\text { was associated with } \\
\text { a significant } 47 \% \\
\text { reduction in the risk } \\
\text { of developing } \\
\text { all-cause dementia. }\end{array}$ & {$[60]$} \\
\hline 8085 & $\begin{array}{c}\text { AD } 183 \\
\text { Three-City cohort } \\
\text { study France }\end{array}$ & $\begin{array}{l}\text { Food frequency } \\
\text { questionnaire }\end{array}$ & 3.48 years & $\begin{array}{c}\text { Frequent } \\
\text { consumption of } \\
\text { fruits and vegetables, } \\
\text { fish, and omega-3 } \\
\text { rich oils may } \\
\text { decrease the risk of } \\
\text { dementia and } \\
\text { Alzheimer's disease, } \\
\text { especially among } \\
\text { ApoE } \varepsilon 4 \text { noncarriers. }\end{array}$ & {$[61]$} \\
\hline 5395 & $\begin{array}{l}\text { Rotterdam Study } \\
\text { The Netherlands }\end{array}$ & $\begin{array}{l}\text { Semiquantitative } \\
\text { food frequency } \\
\text { questionnaire }\end{array}$ & 9.6 years & $\begin{array}{c}\text { In the cohort with } \\
\text { moderate } \\
\text { consumption of fish } \\
\text { and omega-3 PUFAs } \\
\text { these dietary factors } \\
\text { did not appear to be } \\
\text { associated with } \\
\text { long-term dementia } \\
\text { risk }\end{array}$ & {$[62]$} \\
\hline 923 & $\begin{array}{c}\text { AD Rush } \\
\text { Memory and } \\
\text { Aging Project } \\
\text { USA }\end{array}$ & $\begin{array}{l}\text { Semiquantitative } \\
\text { food frequency } \\
\text { questionnaire }\end{array}$ & 4.5 years & $\begin{array}{l}\text { High adherence to all } \\
\text { three diets may } \\
\text { reduce AD risk. }\end{array}$ & [63] \\
\hline
\end{tabular}

The Rotterdam Study was the first to report that fish intake was inversely related to incidence of dementia, in particular to Alzheimer's disease [57]. The data are confirmed by subsequent studies where the consumption of omega-3 [58] or fatty fish [59] or adherence to a diet rich in fruit, vegetables, fish, and oils rich in omega-3 [60-63], is associated with a reduction in AD risk. Subjects that had a mean DHA intake of $0.18 \mathrm{~g} /$ die (mean fish intake of three servings per week) have a lower relative risk of developing dementia if compared with subjects assuming lower DHA intake $(0.15 \mathrm{~g} /$ die corresponding to mean fish intake of two servings per week).

Only a study published by Devore et al. [62] showed that differential consumption of fish (either $8.2 \mathrm{~g} /$ die or $29.6 \mathrm{~g} /$ die, defined as low or high medians) and omega-3 PUFAs, does not appear to be associated with long-term dementia risk. Results were also null for dietary intakes of EPA $(0.03-0.08 \mathrm{~d} / \mathrm{die})$ and DHA $(0.002-0.16 \mathrm{~g} / \mathrm{die})$ considering $\mathrm{AD}$ as the outcome of interest.

\subsection{The Role of Omega-3 Polyunsaturated Fatty Acids in AD: Randomized, Double-Blind, Placebo-Controlled Clinical Trials}

The first randomized clinical trial controlled by placebo (OmegAD Study) that evaluated omega-3 fatty acids' impact in AD was published in 2006 [64] (Tables 3 and 7).

A study by Freund-Levi et al. [64] evaluated omega-3 fatty acids' supplementation in 204 subjects with mild to moderate AD. The active group received daily omega- 3 fatty acids ( $1720 \mathrm{mg}$ DHA and $600 \mathrm{mg}$ EPA) while the placebo group received $4000 \mathrm{mg}$ of corn oil (containing $2400 \mathrm{mg}$ LA) for six months. Both groups received an additional six-month supplementation with omega-3 fatty acids. Medication for AD treatment was allowed. No significant difference was shown after a 6- or 12-month treatment between groups in Alzheimer's disease assessment scale-cognitive subscale (ADAS-cog), mini-mental state examination (MMSE) and clinical dementia rating (CDR). 
Table 7. Clinical trials assessing the impact of omega-3 fatty acids supplementation in AD patients.

\begin{tabular}{|c|c|c|c|c|c|}
\hline $\mathbf{N}^{\circ}$ Patients & $\begin{array}{c}\text { Population } \\
\text { Characteristic }\end{array}$ & $\begin{array}{l}\text { Type and Dose } \\
\text { Supplementation }\end{array}$ & $\begin{array}{l}\text { Exposure } \\
\text { Period }\end{array}$ & Results & References \\
\hline 204 & $\begin{array}{c}\text { AD (DSM-IV) } \\
\text { MMSE 15-30 } \\
\text { OmegAD Study }\end{array}$ & $\begin{array}{c}1720 \mathrm{mg} / \text { die DHA+ } \\
600 \mathrm{mg} / \text { die EPA } \\
\text { Placebo: } 4000 \mathrm{mg} \\
\text { corn oil } \\
\text { Both groups: + } 16 \\
\text { mg/die vitamin E }\end{array}$ & 12 months & $\begin{array}{c}\text { There was no } \\
\text { significant statistical } \\
\text { difference after 6- or } \\
\text { 12-month treatment } \\
\text { between groups in } \\
\text { MMSE, ADAS-cog, } \\
\text { CDR. A subgroup } \\
\text { with very mild } \\
\text { cognitive } \\
\text { dysfunction showed } \\
\text { a reduction in } \\
\text { decline rate. }\end{array}$ & [64] \\
\hline 204 & $\begin{array}{l}\text { AD (DSM-IV) } \\
\text { MMSE 15-30 } \\
\text { OmegAD Study }\end{array}$ & $\begin{array}{c}1720 \mathrm{mg} / \text { die DHA+ } \\
600 \mathrm{mg} / \text { die EPA } \\
\text { Placebo: } 4000 \mathrm{mg} \\
\text { corn oil } \\
\text { Both groups: + } 16 \\
\text { mg vitamin E }\end{array}$ & 12 months & $\begin{array}{l}\text { Supplementation } \\
\text { with omega-3 did not } \\
\text { result in marked } \\
\text { effects on } \\
\text { neuropsychiatric } \\
\text { symptoms except for } \\
\text { possible positive } \\
\text { effects on depressive } \\
\text { symptoms (assessed } \\
\text { by MADRS) in } \\
\text { non-APOE } 4 \text { carriers } \\
\text { and agitation } \\
\text { symptoms (assessed } \\
\text { by NPI) in APOE } 4 \\
\text { carriers. }\end{array}$ & [65] \\
\hline 46 & $\begin{array}{c}\text { AD } \\
\text { AD (DSM-IV) } \\
\text { MMSE 10-26 } \\
\text { CDR-score 1-2 }\end{array}$ & $\begin{array}{l}720 \mathrm{mg} / \text { die DHA+ } \\
1080 \mathrm{mg} / \text { die EPA } \\
\text { Placebo: Olive oil } \\
\text { Both groups: }+1.2 \\
\text { mg hydroquinone }+ \\
12 \text { mg tocopherols }\end{array}$ & 6 months & $\begin{array}{l}\text { The treated group } \\
\text { did not show an } \\
\text { improvement in } \\
\text { cognitive symptoms } \\
\text { measured by MMSE, } \\
\text { ADAS-cog, HDR but } \\
\text { a relative } \\
\text { improvement in } \\
\text { CIBIC-plus score. In } \\
\text { a subgroup with } \\
\text { subjects with mild } \\
\text { cognitive } \\
\text { impairment (MMSE } \\
>27 \text { e CDR 0.5-1) } \\
\text { there was an } \\
\text { improvement in } \\
\text { ADAS-cog. }\end{array}$ & [66] \\
\hline 402 & $\begin{array}{l}\text { AD MMSE 14-26 } \\
\text { Alzheimer's } \\
\text { Disease } \\
\text { Cooperative Study } \\
\text { (ADCS) DHA } \\
\text { Supplementation } \\
\text { Trial USA }\end{array}$ & $\begin{array}{l}2000 \mathrm{mg} / \text { die DHA } \\
\text { from seaweed } \\
\text { Placebo: Corn or soy } \\
\text { oil }\end{array}$ & 18 months & $\begin{array}{c}\text { Supplementation } \\
\text { with DHA compared } \\
\text { with placebo did not } \\
\text { slow the rate of } \\
\text { cognitive and } \\
\text { functional decline in } \\
\text { patients with mild to } \\
\text { moderate } \\
\text { Alzheimer's disease } \\
\text { assessed by MMSE, } \\
\text { ADAS-cog, CDR, } \\
\text { ADS-ADL, NPI. }\end{array}$ & [67] \\
\hline
\end{tabular}


Table 7. Cont.

\begin{tabular}{|c|c|c|c|c|c|}
\hline $\mathbf{N}^{\circ}$ Patients & $\begin{array}{l}\text { Population } \\
\text { Characteristic }\end{array}$ & $\begin{array}{c}\text { Type and Dose } \\
\text { Supplementation }\end{array}$ & $\begin{array}{l}\text { Exposure } \\
\text { Period }\end{array}$ & Results & References \\
\hline 225 & $\begin{array}{l}\text { AD Souvenir I } \\
\text { Study }\end{array}$ & $\begin{array}{c}1700 \text { mg/die DHA+ } \\
600 \text { mg/die EPA } \\
\text { (Souvenaid) } \\
\text { Placebo: Control } \\
\text { drink }\end{array}$ & 6 months & $\begin{array}{c}\text { Supplementation } \\
\text { with omega -3 } \\
\text { improved delayed } \\
\text { verbal recall. } \\
\text { However, ADAS-cog, } \\
\text { CIBIC-plus, NPI, } \\
\text { ADCS-ADL, } \\
\text { ADSC-ADL were } \\
\text { unchanged. }\end{array}$ & [68] \\
\hline 225 & $\begin{array}{l}\text { AD Souvenir I } \\
\text { Study }\end{array}$ & $\begin{array}{c}1700 \text { mg/die DHA+ } \\
600 \text { mg/die EPA } \\
\text { (Souvenaid) } \\
\text { Placebo: Control } \\
\text { drink }\end{array}$ & 6 months & $\begin{array}{l}\text { Souvenaid had a } \\
\text { positive result on } \\
\text { ADAS-cog outcome. } \\
\text { A higher intake of } \\
\text { Souvenaid was also } \\
\text { associated with } \\
\text { greater cognitive } \\
\text { benefit. }\end{array}$ & [69] \\
\hline 238 & $\begin{array}{l}\text { AD Souvenir II } \\
\text { Study }\end{array}$ & $\begin{array}{c}1200 \mathrm{mg} / \text { die DHA+ } \\
300 \mathrm{mg} / \text { die EPA } \\
\text { (Souvenaid) } \\
\text { Placebo: Control } \\
\text { products }\end{array}$ & 6 months & $\begin{array}{l}\text { In the active group, } \\
\text { the NTB memory } \\
\text { domain increased. }\end{array}$ & {$[70]$} \\
\hline 527 & $\begin{array}{l}\text { AD MMSE } 14-24 \\
\text { Connect Study }\end{array}$ & $\begin{array}{c}1200 \mathrm{mg} / \text { die DHA+ } \\
300 \mathrm{mg} / \text { die EPA } \\
\text { (Souvenaid) } \\
\text { Placebo: Control } \\
\text { products }\end{array}$ & 6 months & $\begin{array}{c}\text { Cognitive } \\
\text { performance, as } \\
\text { assessed by } \\
\text { ADAS-cog, showed a } \\
\text { decline over time in } \\
\text { both control and } \\
\text { active study groups, } \\
\text { with no significant } \\
\text { difference between } \\
\text { study groups. } \\
\text { Add-on intake of } \\
\text { Souvenaid did not } \\
\text { slow cognitive } \\
\text { decline in persons } \\
\text { treated for } \\
\text { mild-to-moderate } \\
\text { AD. }\end{array}$ & [71] \\
\hline 174 & $\begin{array}{l}\text { AD mild to } \\
\text { moderate } \\
\text { OmegAD Study }\end{array}$ & $\begin{array}{c}1720 \mathrm{mg} / \text { die DHA+ } \\
600 \mathrm{mg} / \mathrm{die} \mathrm{EPA} \\
\text { Placebo: } 4000 \mathrm{mg} \\
\text { corn oil }\end{array}$ & 12 months & $\begin{array}{l}\text { Plasma transthyretin } \\
\text { positively correlated } \\
\text { with MMSE and } \\
\text { inversely with } \\
\text { ADAS-Cog, } \\
\text { suggesting a } \\
\text { potential mechanism } \\
\text { for probable positive } \\
\text { effects of omega-3 on } \\
\text { cognition. }\end{array}$ & {$[72]$} \\
\hline 39 & $\begin{array}{l}\text { AD MMSE 15-26 } \\
\text { CDR 0.5-1.0 Not } \\
\text { depressed (CESD } \\
<4.0)\end{array}$ & $\begin{array}{c}675 \mathrm{mg} / \text { die DHA+ } \\
975 \mathrm{mg} / \text { die EPA } \\
\text { Group omega-3 plus } \\
\text { alpha lipoic acid } \\
\text { (LA): } 675 \mathrm{mg} / \text { die } \\
\text { DHA+ } 975 \mathrm{mg} / \text { die } \\
\text { EPA+ } 600 \mathrm{mg} / \text { die LA } \\
\text { Placebo: Soy oil }\end{array}$ & 12 months & $\begin{array}{l}\text { Active groups were } \\
\text { no different from the } \\
\text { placebo group in } \\
\text { ADAS-cog, ADL. } \\
\text { Omega-3 + LA group } \\
\text { showed less decline } \\
\text { assessed by MMSE. } \\
\text { IADL differences } \\
\text { between placebo e } \\
\text { omega-3 and } \\
\text { between placebo e } \\
\text { omega-3 + LA } \\
\text { groups were } \\
\text { observed. }\end{array}$ & [73] \\
\hline
\end{tabular}


Table 7. Cont.

\begin{tabular}{|c|c|c|c|c|c|}
\hline $\mathbf{N}^{\circ}$ Patients & $\begin{array}{c}\text { Population } \\
\text { Characteristic }\end{array}$ & $\begin{array}{l}\text { Type and Dose } \\
\text { Supplementation }\end{array}$ & $\begin{array}{l}\text { Exposure } \\
\text { Period }\end{array}$ & Results & References \\
\hline 179 & $\begin{array}{l}\text { AD mild Souvenir } \\
\text { II Study }\end{array}$ & $\begin{array}{c}1700 \text { mg/die DHA+ } 6 \\
\text { mg/die EPA } \\
\text { (Souvenaid) } \\
\text { Placebo: Control } \\
\text { drink }\end{array}$ & 6 months & $\begin{array}{l}\text { The administration } \\
\text { contributed to the } \\
\text { maintenance of the } \\
\text { organization of brain } \\
\text { networks in mild AD } \\
\text { patients. }\end{array}$ & [74] \\
\hline 19 & AD MMSE 16-30 & $\begin{array}{c}625 \mathrm{mg} / \text { die DHA+ } \\
600 \mathrm{mg} / \text { die EPA } \\
\text { Placebo: Olive oil } \\
\text { Both groups: }+20 \\
\text { mg mixed } \\
\text { tocopherols }\end{array}$ & 4 months & $\begin{array}{c}\text { The daily } \\
\text { supplementation } \\
\text { was associated with } \\
\text { none or only } \\
\text { negligible benefits on } \\
\text { mood and cognition, } \\
\text { assessed by MMSE, } \\
\text { HVLT-R, BASDEC, } \\
\text { BADLS. }\end{array}$ & [75] \\
\hline 204 & $\begin{array}{l}\text { AD OmegAD } \\
\text { Study }\end{array}$ & $\begin{array}{l}1720 \mathrm{mg} / \text { die DHA+ } \\
600 \mathrm{mg} / \text { die EPA } \\
\text { Placebo: } 4000 \mathrm{mg} \\
\text { corn oil Both groups: } \\
+16 \mathrm{mg} \text { vitamin E }\end{array}$ & 6 months & $\begin{array}{l}\text { The daily } \\
\text { supplementation } \\
\text { stabilized the } \\
\text { cognitive } \\
\text { performance of AD } \\
\text { subjects, assessed by } \\
\text { ADAS-cog and } \\
\text { MMSE scores. }\end{array}$ & [76] \\
\hline 204 & $\begin{array}{l}\text { AD OmegAD } \\
\text { Study }\end{array}$ & $\begin{array}{l}1720 \mathrm{mg} / \text { die DHA+ } \\
600 \mathrm{mg} / \text { die EPA } \\
\text { Placebo: } 4000 \mathrm{mg} \\
\text { corn oil Both groups: } \\
+16 \mathrm{mg} \text { vitamin E }\end{array}$ & 6 months & $\begin{array}{c}\text { A decrease was } \\
\text { observed in RvD1 } \\
\text { and LXA4 } \\
\text { production from } \\
\text { peripheral blood } \\
\text { mononuclear cells of } \\
\text { AD patients who did } \\
\text { not receive omega-3 } \\
\text { but not in cells of AD } \\
\text { subjects under } \\
\text { omega-3 intake. }\end{array}$ & [77] \\
\hline 201 & $\begin{array}{l}\text { AD Open label } \\
\text { extension study } \\
\text { (OLE) Souvenir II } \\
\text { MMSE } \geq 20\end{array}$ & $\begin{array}{c}1200 \text { mg/die DHA+ } \\
300 \text { mg/die EPA } \\
\text { (Souvenaid) } \\
\text { Placebo: Control } \\
\text { drink }\end{array}$ & 6 months & $\begin{array}{l}\text { The intake of } \\
\text { Souvenaid was well } \\
\text { tolerated with a } \\
\text { favorable safety } \\
\text { profile. The } \\
\text { adherence to } \\
\text { Souvenaid was very } \\
\text { high reflecting its } \\
\text { good tolerability and } \\
\text { ease of use. }\end{array}$ & [78] \\
\hline 171 & $\begin{array}{l}\text { AD OmegAD } \\
\text { Study }\end{array}$ & $\begin{array}{l}1720 \mathrm{mg} / \text { die DHA+ } \\
600 \mathrm{mg} / \text { die EPA } \\
\text { Placebo: } 1 \mathrm{~g} \text { corn oil } \\
\text { Both groups: }+16 \\
\text { mg vitamin E }\end{array}$ & 6 months & $\begin{array}{l}\text { The effect of omega-3 } \\
\text { supplementation on } \\
\text { MMSE and CDR } \\
\text { appeared to be } \\
\text { influenced by } \\
\text { homocysteine } \\
\text { plasma levels. }\end{array}$ & [79] \\
\hline
\end{tabular}

In a subgroup with very mild AD (MMSE $>27$ and CDR 0.5-1), there was a significant reduction in decline rate between the intervention and placebo groups in the first six months.

In a second paper published in 2008, Freund-Levi et al. [65], using the same sample from 2006, showed that supplementation with omega-3 in patients with mild to moderate AD did not result in marked effects on neuropsychiatric symptoms except from possible positive effects on depression (assessed by MADRS) in non-APOE 4 carriers and agitation symptoms (assessed by Neuropsychiatric Inventory, NPI) in APOE $\varepsilon 4$ carriers. The omega-3 mechanism of action in the brain in relation to 
behavior is not fully elucidated. It has been shown in in vitro studies that a combination of EPA and DHA inhibits protein kinase C (PKC) activity [65]. Since mood stabilizers are known to inhibit PKC activity as well, PKC inhibition may represent a common mode of action for omega-3 in bipolar disorders. Other possible mechanisms could be that omega- 3 fatty acids affect neurotransmitter levels and membrane fluidity also by decreasing production of pro-inflammatory eicosanoids that might be elevated in depression [65].

Chiu et al. [66] studied 46 subjects with mild to moderate AD or mild cognitive impairment (DSM-IV: MMSE 10-26, CDR-score 1-2). During six months, the intervention group received $720 \mathrm{mg} /$ die DHA and $1080 \mathrm{mg} /$ die EPA, while the placebo group received olive oil. Medication for AD treatment was not allowed. There was no significant statistical difference in MMSE, ADAS-cog, and HDRS between the two groups. The negative results of cognitive assessments support the previous studies by Freund-Levi et al. [64,65], and all of the studies showed there might be a positive effect of omega-3 fatty acids only in subgroups with mild cognitive deficits. A significant improvement was observed in clinician interview-based impression of change, plus carer interview (CIBIC-plus) in the intervention group compared to the placebo group. This might be explained considering the cognitive and behavioral aspects rather than the functional one. Omega- 3 fatty acids may have been proposed to have beneficial effects on mood, although this is an unlikely explanation for these results because of the rigorous exclusion of people with significant depression and the absence of association with HDRS score. The relative progress of general clinical conditions might have been caused by improvement in cardiovascular or immunological systems induced by omega-3 [66].

In a subgroup, participants with mild cognitive impairment (MMSE $>27$ e CDR 0.5-1) but not with $\mathrm{AD}$, showed a significant additional delay in ADAS-cog, decline compared to the placebo group.

Quinn et al. [67] assessed 402 subjects with mild to moderate AD. The intervention group received DHA $2000 \mathrm{mg} /$ die from seaweed and the placebo group received corn or soy oil for 18 months. Medication for AD treatment was allowed. Supplementation with DHA compared with placebo did not slow the rate of cognitive and functional decline in patients with mild to moderate Alzheimer's disease (no beneficial effect on the rate of change on MMSE, ADAS-cog, CDR, ADS-ADL, and NPI).

Sheltens et al. [68] assessed 225 subjects with mild AD. The intervention group received DHA $1700 \mathrm{mg} /$ die and EPA $600 \mathrm{mg} /$ die from a medical food named Souvenaid and the placebo group received a control drink for six months. Significant improvement in the delayed verbal recall task was noted in the supplemented group compared with control. ADAS-cog and other outcome scores (CIBIC-plus, NPI, ADCS-ADL) remained unchanged.

The same authors published a study [69] where the same above-mentioned population was divided into two subgroups: Patients with 'low' baseline ADAS-cog scores $(<25.0)$ and patients with 'high' baseline ADAS-cog scores $(\geq 25.0)$. Repeated measures models were used to determine the relationship between ADAS-cog score and intervention. Baseline ADAS-cog significantly influenced the effect of Souvenaid intervention on ADAS-cog outcome. A higher intake of medical food was also associated with greater cognitive benefit.

Based on these results, two double-blind, randomized controlled clinical trials were designed. The Souvenir II study examined the effect of longer treatment duration (six months) with Souvenaid, as compared with control product on memory performance in drug-naïve mild AD [70]. Neuropsychological test battery (NTB) memory domain increased in the active group.

Considering that ADAS-cog could be considerably modified in moderate AD and that Souvenaid had not been evaluated in patients with moderate $\mathrm{AD}$ already taking $\mathrm{AD}$ medications, a novel S-Connect study was planned. This double-blind, parallel, randomized, controlled clinical study, investigated the efficacy and tolerability of Souvenaid in 527 persons with mild to moderate AD, consuming constant doses of Souvenaid [71]. Cognitive performance evaluated by ADAS-cog, showed a decline over time in either placebo or active groups, indicating no significant difference between active groups themselves. Souvenaid drinking did not decelerate cognitive decline in patients treated for mild to moderate AD. Faxen-Irving et al., as a part of a previously published study on a DHA 
rich supplementation to subjects with AD [64], explored the effects of transthyretin on plasma and CSF. Since plasma transthyretin correlated with MMSE and inversely with ADAS-Cog, these authors suggest a potential mechanism for probable positive effects of omega-3 on cognition.

A study from Shinto et al. [73] investigated 39 subjects with probable AD in a randomized placebo-controlled pilot with three arms, one group receiving only omega- 3 fatty acids (DHA $675 \mathrm{mg} / \mathrm{die}$ and EPA $975 \mathrm{mg} / \mathrm{die})$, the second with the addition of alpha lipoic acid (600 mg/die), and the placebo group receiving soy oil. The intervention lasted 12 months and medication for AD was allowed. No differences were found in ADAS-cog and ADL between placebo and omega- 3 fatty acids or between placebo and omega-3 fatty acids + alpha lipoic acid. In MMSE, the mean variation between the placebo group and the intervention group with only omega- 3 fatty acids was not significant, whereas the difference between placebo and omega- 3 fatty acids + alpha lipoic acid was significant. The mean IADL variation (Table 3 ) was significant between the placebo group and the omega-3 fatty acid group and between the placebo and the omega-3 fatty acids + alpha lipoic acid group.

In a secondary analysis of the Souvenir II study [74], results suggest that Souvenaid maintains the brain networks' organization in patients with mild AD within six months, theoretically contrasting with the progressive network disruption over time in AD. These results strongly support the hypothesis that Souvenaid influences synaptic integrity and functioning.

Phillips et al. [75] assessed omega-3 fatty acids' supplementation in 19 subjects with AD. The intervention group received daily omega-3 fatty acids in the dosages of $625 \mathrm{mg}$ DHA and $600 \mathrm{mg}$ EPA and the placebo group received olive oil for four months. The daily supplementation was associated with none or only negligible benefits on mood and cognition assessed by MMSE, the Hopkins verbal learning test-revised (HVLT-R), brief assessment schedule depression cards (BASDEC) and Bristol's activities of daily living scale (BADLS).

Data obtained in the OmegAD study $[65,80]$ were collected to examine the relationship of plasma omega-3 levels with cognitive scores (using ADAS-cog and the MMSE) [76]. The daily supplementation stabilizes the cognitive performance of AD subjects assessed by ADAS-cog and MMSE scores.

Also from the OmegAD study, a decrease was observed in resolvin D1 (RvD1) and lipoxin $\mathrm{A}_{4}$ $\left(\mathrm{LXA}_{4}\right)$ production from peripheral blood mononuclear cells of $\mathrm{AD}$ patients who did not receive omega-3 supplementation but not in the cells of AD subjects under omega-3 intake [77].

Recent systematic meta-analysis did not show any significant benefits of omega- 3 fatty acids supplementation in the treatment of mild to moderate $\mathrm{AD}$, even if the treatment did not raise any substantial safety issues [13]. In fact, studies concerning the tolerability, safety, and effect size of Souvenaid demonstrated that the use of medical food for up to 12 months was well tolerated, with a favorable safety profile and high adherence of intake [78,81]. Moreover, the efficacy of omega-3 supplementation seems to be influenced by the baseline levels of plasma total homocysteine, suggesting that adequate $B$ vitamin status is required to obtain beneficial effects of omega- 3 on cognitive performance in moderate $\mathrm{AD}$ [79].

\section{Materials and Methods}

The authors searched PubMed, Web of Science, and Scopus articles using a combination of "omega-3 fatty acids,", "Parkinson's Disease, "Alzheimer's Disease", "clinical trials" as keywords. Inclusion criteria consisted of original intervention studies, controlled by placebo, that assessed omega-3 polyunsaturated fatty acids impact on cognitive function in humans with PD or AD, until May 2019, without restriction for the initial date of publication. We searched for interventions using omega-3 polyunsaturated fatty acids as dietary supplements or as increased dietary intake (such as fish or fish oils). First, we evaluated the titles and abstracts, then, we completed the reading of the full texts. Two reviewers independently performed the paper search, selection, and result extraction.

In order to favor reliability, data were collected independently in a table including the number of patients, population characteristics, type and dose of supplementation, exposure period, results and references. The authors prepared references using Zotero as bibliography software. 


\section{Conclusions}

Neurodegenerative conditions, such as Parkinson's disease and Alzheimer's disease, represent a challenging issue in clinical medicine, and their burden is expected to increase dramatically in the forthcoming decades. At the present time, no etiological treatment is routinely available, and medical therapy is mainly symptomatic. The adoption of a nutritional approach would be highly recommendable.

Omega-3 fatty acids represent an interesting biological potential, in view of their anti-inflammatory and metabolic properties, in the management of these diseases.

Indeed, the evidence deriving from prospective observational studies is encouraging, both for Parkinson's and Alzheimer's disease. The adoption of a dietary regimen enriched with omega-3 fatty acids rather consistently associates with a reduced risk of either condition. On the other hand, randomized trials have provided conflicting results, and many of them have failed to document a definite protective effect. This was confirmed by most reviews and meta-analyses performed so far.

The inconsistency between observational and randomized studies is not unusual in clinical research, particularly when considering treatment with dietary supplements or integrators. A number of reasons may account for this finding. Firstly, in controlled trials, dietary supplementation is usually carried out over a relatively limited time span, compared with the life-long exposure of real-life observational studies. The different time course of the two approaches could play a relevant role. Observational studies may disclose the preventive effects of disease initiation, whereas in randomized trials involving patients already carrying a disease, the outcome more likely consists of a slowing of disease progression, or a reduction in disease-related complications. Distinct protective mechanisms are likely to take place. Furthermore, the variations in dietary patterns might reflect the adoption of a healthier lifestyle, in adjunct to the contribution provided by the single-nutrient supplementation. This was postulated, for instance, when investigating the protective effects of the Mediterranean diet on cognitive performances. In the present context, the intake of higher amounts of foods containing omega-3 fatty acids might be associated with a reduced intake of other nutrients, such as meat.

Finally, the possibility of different individual responses to dietary intervention must be considered. As mentioned in this review, the protective effects exerted by omega-3 fatty acids are likely to be modulated by patient-related factors, some of which may have a significant genetic component and may, therefore, be unmodifiable, and unpredictable with routine clinical and biochemical evaluation.

At any rate, treatment with omega-3 fatty acids was generally reported to be safe and well-tolerated. In our opinion, they may indeed represent a valuable and biologically plausible tool in the management of neurodegenerative diseases. Of course, supplementation needs to be a part of a global lifestyle intervention and has to take place in the early stages of the disease, when a benefit may be detected. Hopefully, in the near future the adoption of personalized treatment strategies, aimed to predict individual responses, will help to optimize the effectiveness of such intervention, in order to face the progressive rise of these devastating conditions.

Author Contributions: Conceptualization, R.A.; methodology, R.A., G.V. and M.B.; writing-original draft preparation, R.A.; writing-review and editing, G.V. and M.B.; supervision, M.B.; funding acquisition, G.V.

Funding: This work was supported by the Fondazione Cassa di Risparmio di Modena Grant n.2018.0334.

Acknowledgments: The authors would like to thank Lorenzo Corsi for his useful contribution to manuscript's figures.

Conflicts of Interest: The authors declare no conflict of interest.

\section{Abbreviations}

$\begin{array}{ll}\text { 5-LOX } & \text { 5-lipoxygenase } \\ \text { AD } & \text { Alzheimer's disease } \\ \text { ADAS-Cog } & \text { Alzheimer's disease assessment scale-cognitive subscale } \\ \text { ADCS } & \text { Activities of daily living scales } \\ \text { ALA } & \alpha \text { linolenic acid }\end{array}$




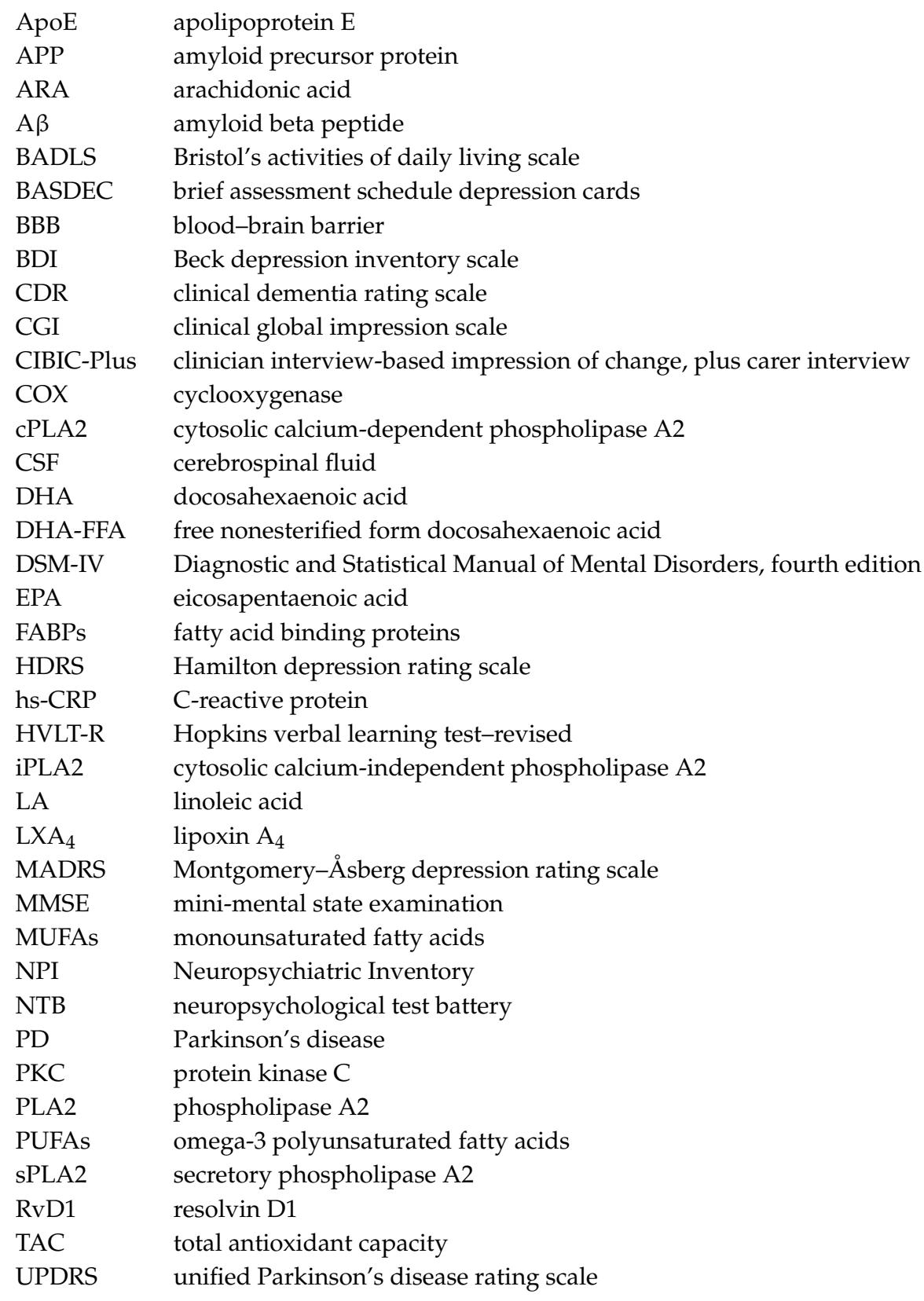

\section{References}

1. Cansev, M.; Wurtman, R.J.; Sakamoto, T.; Ulus, I.H. Oral Administration of Circulating Precursors for Membrane Phosphatides Can Promote the Synthesis of New Brain Synapses. Alzheimers Dement. J. Alzheimers Assoc. 2008, 4, S153-S168. [CrossRef] [PubMed]

2. Beltz, B.S.; Tlusty, M.F.; Benton, J.L.; Sandeman, D.C. Omega-3 Fatty Acids Upregulate Adult Neurogenesis. Neurosci. Lett. 2007, 415, 154-158. [CrossRef] [PubMed]

3. Kawakita, E.; Hashimoto, M.; Shido, O. Docosahexaenoic Acid Promotes Neurogenesis in Vitro and in Vivo. Neuroscience 2006, 139, 991-997. [CrossRef] [PubMed]

4. Cutuli, D. Functional and Structural Benefits Induced by Omega-3 Polyunsaturated Fatty Acids During Aging. Curr. Neuropharmacol. 2017, 15, 534-542. [CrossRef] [PubMed]

5. Aryal, S.; Hussain, S.; Drevon, C.A.; Nagelhus, E.; Hvalby, Ø.; Jensen, V.; Walaas, S.I.; Davanger, S. Omega-3 Fatty Acids Regulate Plasticity in Distinct Hippocampal Glutamatergic Synapses. Eur. J. Neurosci. 2019, 49, 40-50. [CrossRef] [PubMed] 
6. Castro-Gómez, P.; Garcia-Serrano, A.; Visioli, F.; Fontecha, J. Relevance of Dietary Glycerophospholipids and Sphingolipids to Human Health. Prostaglandins Leukot. Essent. Fat. Acids 2015, 101, 41-51. [CrossRef] [PubMed]

7. Cardoso, C.; Afonso, C.; Bandarra, N.M. Dietary DHA and Health: Cognitive Function Ageing. Nutr. Res. Rev. 2016, 29, 281-294. [CrossRef]

8. Calviello, G.; Su, H.-M.; Weylandt, K.H.; Fasano, E.; Serini, S.; Cittadini, A. Experimental Evidence of $\omega-3$ Polyunsaturated Fatty Acid Modulation of Inflammatory Cytokines and Bioactive Lipid Mediators: Their Potential Role in Inflammatory, Neurodegenerative, and Neoplastic Diseases. Biomed Res. Int. 2013, 2013. [CrossRef]

9. Moore, K.; Hughes, C.F.; Ward, M.; Hoey, L.; McNulty, H. Diet, Nutrition and the Ageing Brain: Current Evidence and New Directions. Proc. Nutr. Soc. 2018, 77, 152-163. [CrossRef]

10. Yassine, H.N.; Braskie, M.N.; Mack, W.J.; Castor, K.J.; Fonteh, A.N.; Schneider, L.S.; Harrington, M.G.; Chui, H.C. Association of Docosahexaenoic Acid Supplementation with Alzheimer Disease Stage in Apolipoprotein E E4 Carriers: A Review. JAMA Neurol. 2017, 74, 339-347. [CrossRef]

11. Araya-Quintanilla, F.; Gutiérrez-Espinoza, H.; Sánchez-Montoya, U.; Muñoz-Yañez, M.J.; Baeza-Vergara, A.; Petersen-Yanjarí, M.; Fernández-Lecaros, L. Effectiveness of Omega-3 Fatty Acid Supplementation in Patients with Alzheimer Disease: A Systematic Review and Meta-Analysis. Neurol. Barc. Spain 2017. [CrossRef]

12. Butler, M.; Nelson, V.A.; Davila, H.; Ratner, E.; Fink, H.A.; Hemmy, L.S.; McCarten, J.R.; Barclay, T.R.; Brasure, M.; Kane, R.L. Over-the-Counter Supplement Interventions to Prevent Cognitive Decline, Mild Cognitive Impairment, and Clinical Alzheimer-Type Dementia: A Systematic Review. Ann. Intern. Med. 2018, 168, 52-62. [CrossRef] [PubMed]

13. Burckhardt, M.; Herke, M.; Wustmann, T.; Watzke, S.; Langer, G.; Fink, A. Omega-3 Fatty Acids for the Treatment of Dementia. Cochrane Database Syst. Rev. 2016, 4. [CrossRef] [PubMed]

14. Weiser, M.J.; Butt, C.M.; Mohajeri, M.H. Docosahexaenoic Acid and Cognition throughout the Lifespan. Nutrients 2016, 8, 1223. [CrossRef] [PubMed]

15. Chappus-McCendie, H.; Chevalier, L.; Roberge, C.; Plourde, M. Omega-3 PUFA Metabolism and Brain Modifications during Aging. Prog. Neuropsychopharmacol. Biol. Psychiatry 2019, 94. [CrossRef] [PubMed]

16. Brenna, J.T.; Diau, G.-Y. The Influence of Dietary Docosahexaenoic Acid and Arachidonic Acid on Central Nervous System Polyunsaturated Fatty Acid Composition. Prostaglandins Leukot. Essent. Fat. Acids 2007, 77, 247-250. [CrossRef] [PubMed]

17. Wassall, S.R.; Leng, X.; Canner, S.W.; Pennington, E.R.; Kinnun, J.J.; Cavazos, A.T.; Dadoo, S.; Johnson, D.; Heberle, F.A.; Katsaras, J.; et al. Docosahexaenoic Acid Regulates the Formation of Lipid Rafts: A Unified View from Experiment and Simulation. Biochim. Biophys. Acta Biomembr. 2018, 1860, 1985-1993. [CrossRef]

18. Uauy, R.; Dangour, A.D. Nutrition in Brain Development and Aging: Role of Essential Fatty Acids. Nutr. Rev. 2006, 64, S24-S33. [CrossRef]

19. De Bus, I.; Witkamp, R.; Zuilhof, H.; Albada, B.; Balvers, M. The Role of N-3 PUFA-Derived Fatty Acid Derivatives and Their Oxygenated Metabolites in the Modulation of Inflammation. Prostaglandins Other Lipid Mediat. 2019, 144. [CrossRef]

20. Janssen, C.I.F.; Kiliaan, A.J. Long-Chain Polyunsaturated Fatty Acids (LCPUFA) from Genesis to Senescence: The Influence of LCPUFA on Neural Development, Aging, and Neurodegeneration. Prog. Lipid Res. 2014, 53, 1-17. [CrossRef]

21. Simopoulos, A.P. The Omega-6/Omega-3 Fatty Acid Ratio, Genetic Variation, and Cardiovascular Disease. Asia Pac. J. Clin. Nutr. 2008, 17, 131-134. [PubMed]

22. Schmitz, G.; Ecker, J. The Opposing Effects of N-3 and n-6 Fatty Acids. Prog. Lipid Res. 2008, 47, 147-155. [CrossRef] [PubMed]

23. Chen, S.; Subbaiah, P.V. Regioisomers of Phosphatidylcholine Containing DHA and Their Potential to Deliver DHA to the Brain: Role of Phospholipase Specificities. Lipids 2013, 48, 675-686. [CrossRef] [PubMed]

24. Liu, R.-Z.; Mita, R.; Beaulieu, M.; Gao, Z.; Godbout, R. Fatty Acid Binding Proteins in Brain Development and Disease. Int. J. Dev. Biol. 2010, 54, 1229-1239. [CrossRef] [PubMed]

25. Pan, Y.; Scanlon, M.J.; Owada, Y.; Yamamoto, Y.; Porter, C.J.H.; Nicolazzo, J.A. Fatty Acid-Binding Protein 5 Facilitates the Blood-Brain Barrier Transport of Docosahexaenoic Acid. Mol. Pharm. 2015, 12, 4375-4385. [CrossRef] [PubMed] 
26. Vandal, M.; Alata, W.; Tremblay, C.; Rioux-Perreault, C.; Salem, N.; Calon, F.; Plourde, M. Reduction in DHA Transport to the Brain of Mice Expressing Human APOE4 Compared to APOE2. J. Neurochem. 2014, 129, 516-526. [CrossRef] [PubMed]

27. Ouellet, M.; Emond, V.; Chen, C.T.; Julien, C.; Bourasset, F.; Oddo, S.; LaFerla, F.; Bazinet, R.P.; Calon, F. Diffusion of Docosahexaenoic and Eicosapentaenoic Acids through the Blood-Brain Barrier: An in Situ Cerebral Perfusion Study. Neurochem. Int. 2009, 55, 476-482. [CrossRef] [PubMed]

28. Chen, C.T.; Green, J.T.; Orr, S.K.; Bazinet, R.P. Regulation of Brain Polyunsaturated Fatty Acid Uptake and Turnover. Prostaglandins Leukot. Essent. Fat. Acids 2008, 79, 85-91. [CrossRef]

29. Zárate, R.; El Jaber-Vazdekis, N.; Tejera, N.; Pérez, J.A.; Rodríguez, C. Significance of Long Chain Polyunsaturated Fatty Acids in Human Health. Clin. Transl. Med. 2017, 6, 25. [CrossRef]

30. Murakami, M. Lipoquality Control by Phospholipase A2 Enzymes. Proc. Jpn. Acad. Ser. B Phys. Biol. Sci. 2017, 93, 677-702. [CrossRef]

31. Innes, J.K.; Calder, P.C. Omega-6 Fatty Acids and Inflammation. Prostaglandins Leukot. Essent. Fat. Acids 2018, 132, 41-48. [CrossRef] [PubMed]

32. Tassoni, D.; Kaur, G.; Weisinger, R.S.; Sinclair, A.J. The Role of Eicosanoids in the Brain. Asia Pac. J. Clin. Nutr. 2008, 17 (Suppl. 1), 220-228. [PubMed]

33. Tapiero, H.; Ba, G.N.; Couvreur, P.; Tew, K.D. Polyunsaturated Fatty Acids (PUFA) and Eicosanoids in Human Health and Pathologies. Biomed. Pharm. 2002, 56, 215-222. [CrossRef]

34. Dyall, S.C.; Michael-Titus, A.T. Neurological Benefits of Omega-3 Fatty Acids. Neuromol. Med. 2008, 10, 219-235. [CrossRef] [PubMed]

35. Pawlosky, R.J.; Hibbeln, J.R.; Novotny, J.A.; Salem, N. Physiological Compartmental Analysis of Alpha-Linolenic Acid Metabolism in Adult Humans. J. Lipid Res. 2001, 42, 1257-1265. [PubMed]

36. Brenna, J.T. Efficiency of Conversion of Alpha-Linolenic Acid to Long Chain n-3 Fatty Acids in Man. Curr. Opin. Clin. Nutr. Metab. Care 2002, 5, 127-132. [CrossRef]

37. Burdge, G.C.; Wootton, S.A. Conversion of Alpha-Linolenic Acid to Eicosapentaenoic, Docosapentaenoic and Docosahexaenoic Acids in Young Women. Br. J. Nutr. 2002, 88, 411-420. [CrossRef]

38. Burdge, G.C. Metabolism of Alpha-Linolenic Acid in Humans. Prostaglandins Leukot. Essent. Fat. Acids 2006, 75, 161-168. [CrossRef]

39. Thompson, M.; Hein, N.; Hanson, C.; Smith, L.M.; Anderson-Berry, A.; Richter, C.K.; Stessy Bisselou, K.; Kusi Appiah, A.; Kris-Etherton, P.; Skulas-Ray, A.C.; et al. Omega-3 Fatty Acid Intake by Age, Gender, and Pregnancy Status in the United States: National Health and Nutrition Examination Survey 2003-2014. Nutrients 2019, 11, 177. [CrossRef]

40. Scientific Opinion on the Tolerable Upper Intake Level of Eicosapentaenoic Acid (EPA), Docosahexaenoic Acid (DHA) and Docosapentaenoic Acid (DPA). EFSA J. 2012, 10. [CrossRef]

41. Ghasemi Fard, S.; Wang, F.; Sinclair, A.J.; Elliott, G.; Turchini, G.M. How Does High DHA Fish Oil Affect Health? A Systematic Review of Evidence. Crit. Rev. Food Sci. Nutr. 2019, 59, 1684-1727. [CrossRef] [PubMed]

42. Nguyen, Q.V.; Malau-Aduli, B.S.; Cavalieri, J.; Nichols, P.D.; Malau-Aduli, A.E.O. Enhancing Omega-3 Long-Chain Polyunsaturated Fatty Acid Content of Dairy-Derived Foods for Human Consumption. Nutrients 2019, 11, 743. [CrossRef] [PubMed]

43. Office of Dietary Supplements-Omega-3 Fatty Acids. Available online: https://ods.od.nih.gov/factsheets/ Omega3FattyAcids-HealthProfessional/ (accessed on 7 June 2019).

44. Da Silva, T.M.; Munhoz, R.P.; Alvarez, C.; Naliwaiko, K.; Kiss, Á.; Andreatini, R.; Ferraz, A.C. Depression in Parkinson's Disease: A Double-Blind, Randomized, Placebo-Controlled Pilot Study of Omega-3 Fatty-Acid Supplementation. J. Affect. Disord. 2008, 111, 351-359. [CrossRef] [PubMed]

45. Kamel, F.; Goldman, S.M.; Umbach, D.M.; Chen, H.; Richardson, G.; Barber, M.R.; Meng, C.; Marras, C.; Korell, M.; Kasten, M.; et al. Dietary Fat Intake, Pesticide Use, and Parkinson's Disease. Parkinsonism Relat. Disord. 2014, 20, 82-87. [CrossRef] [PubMed]

46. Elfawy, H.A.; Das, B. Crosstalk between Mitochondrial Dysfunction, Oxidative Stress, and Age Related Neurodegenerative Disease: Etiologies and Therapeutic Strategies. Life Sci. 2019, 218, 165-184. [CrossRef] [PubMed] 
47. Canhada, S.; Castro, K.; Perry, I.S.; Luft, V.C. Omega-3 Fatty Acids' Supplementation in Alzheimer's Disease: A Systematic Review. Nutr. Neurosci. 2018, 21, 529-538. [CrossRef] [PubMed]

48. Abbott, R.D.; Webster Ross, G.; White, L.R.; Sanderson, W.T.; Burchfiel, C.M.; Kashon, M.; Sharp, D.S.; Masaki, K.H.; Curb, J.D.; Petrovitch, H. Environmental, Life-Style, Andphysical Precursors of Clinical Parkinson's Disease: Recentfindings from the Honolulu-Asia Aging Study. J. Neurol. 2003, 250. [CrossRef]

49. De Lau, L.M.L.; Bornebroek, M.; Witteman, J.C.M.; Hofman, A.; Koudstaal, P.J.; Breteler, M.M.B. Dietary Fatty Acids and the Risk of Parkinson Disease: The Rotterdam Study. Neurology 2005, 64, 2040-2045. [CrossRef]

50. Gao, X.; Chen, H.; Fung, T.T.; Logroscino, G.; Schwarzschild, M.A.; Hu, F.B.; Ascherio, A. Prospective Study of Dietary Pattern and Risk of Parkinson Disease. Am. J. Clin. Nutr. 2007, 86, 1486-1494. [CrossRef]

51. Miyake, Y.; Sasaki, S.; Tanaka, K.; Fukushima, W.; Kiyohara, C.; Tsuboi, Y.; Yamada, T.; Oeda, T.; Miki, T.; Kawamura, N.; et al. Dietary Fat Intake and Risk of Parkinson's Disease: A Case-Control Study in Japan. J. Neurol. Sci. 2010, 288, 117-122. [CrossRef]

52. Pomponi, M.; Loria, G.; Salvati, S.; Di Biase, A.; Conte, G.; Villella, C.; Righino, E.; Ciciarelli, C.; Bria, P.; La Torre, G.; et al. DHA Effects in Parkinson Disease Depression. Basal Ganglia 2014, 4, 61-66. [CrossRef]

53. Taghizadeh, M.; Tamtaji, O.R.; Dadgostar, E.; Daneshvar Kakhaki, R.; Bahmani, F.; Abolhassani, J.; Aarabi, M.H.; Kouchaki, E.; Memarzadeh, M.R.; Asemi, Z. The Effects of Omega-3 Fatty Acids and Vitamin E Co-Supplementation on Clinical and Metabolic Status in Patients with Parkinson's Disease: A Randomized, Double-Blind, Placebo-Controlled Trial. Neurochem. Int. 2017, 108, 183-189. [CrossRef] [PubMed]

54. Fernández-Sanz, P.; Ruiz-Gabarre, D.; García-Escudero, V. Modulating Effect of Diet on Alzheimer's Disease. Dis. Basel Switz. 2019, 7, 12. [CrossRef]

55. Grimm, M.O.W.; Michaelson, D.M.; Hartmann, T. Omega-3 Fatty Acids, Lipids, and ApoE Lipidation in Alzheimer's Disease: A Rationale for Multi-Nutrient Dementia Prevention. J. Lipid Res. 2017, 58, $2083-2101$. [CrossRef] [PubMed]

56. Cunnane, S.C.; Plourde, M.; Pifferi, F.; Bégin, M.; Féart, C.; Barberger-Gateau, P. Fish, Docosahexaenoic Acid and Alzheimer's Disease. Prog. Lipid Res. 2009, 48, 239-256. [CrossRef]

57. Kalmijn, S.; Launer, L.J.; Ott, A.; Witteman, J.C.; Hofman, A.; Breteler, M.M. Dietary Fat Intake and the Risk of Incident Dementia in the Rotterdam Study. Ann. Neurol. 1997, 42, 776-782. [CrossRef]

58. Morris, M.C.; Evans, D.A.; Bienias, J.L.; Tangney, C.C.; Bennett, D.A.; Wilson, R.S.; Aggarwal, N.; Schneider, J. Consumption of Fish and N-3 Fatty Acids and Risk of Incident Alzheimer Disease. Arch. Neurol. 2003, 60, 940-946. [CrossRef]

59. Huang, T.L.; Zandi, P.P.; Tucker, K.L.; Fitzpatrick, A.L.; Kuller, L.H.; Fried, L.P.; Burke, G.L.; Carlson, M.C. Benefits of Fatty Fish on Dementia Risk Are Stronger for Those without APOE Epsilon4. Neurology 2005, 65, 1409-1414. [CrossRef]

60. Schaefer, E.J.; Bongard, V.; Beiser, A.S.; Lamon-Fava, S.; Robins, S.J.; Au, R.; Tucker, K.L.; Kyle, D.J.; Wilson, P.W.F.; Wolf, P.A. Plasma Phosphatidylcholine Docosahexaenoic Acid Content and Risk of Dementia and Alzheimer Disease: The Framingham Heart Study. Arch. Neurol. 2006, 63, 1545-1550. [CrossRef]

61. Barberger-Gateau, P.; Raffaitin, C.; Letenneur, L.; Berr, C.; Tzourio, C.; Dartigues, J.F.; Alpérovitch, A. Dietary Patterns and Risk of Dementia: The Three-City Cohort Study. Neurology 2007, 69, 1921-1930. [CrossRef]

62. Devore, E.E.; Grodstein, F.; van Rooij, F.J.A.; Hofman, A.; Rosner, B.; Stampfer, M.J.; Witteman, J.C.M.; Breteler, M.M.B. Dietary Intake of Fish and Omega-3 Fatty Acids in Relation to Long-Term Dementia Risk. Am. J. Clin. Nutr. 2009, 90, 170-176. [CrossRef] [PubMed]

63. Morris, M.C.; Tangney, C.C.; Wang, Y.; Sacks, F.M.; Bennett, D.A.; Aggarwal, N.T. MIND Diet Associated with Reduced Incidence of Alzheimer's Disease. Alzheimers Dement. J. Alzheimers Assoc. 2015, 11, 1007-1014. [CrossRef] [PubMed]

64. Freund-Levi, Y.; Eriksdotter-Jönhagen, M.; Cederholm, T.; Basun, H.; Faxén-Irving, G.; Garlind, A.; Vedin, I.; Vessby, B.; Wahlund, L.-O.; Palmblad, J. Omega-3 Fatty Acid Treatment in 174 Patients with Mild to Moderate Alzheimer Disease: OmegAD Study: A Randomized Double-Blind Trial. Arch. Neurol. 2006, 63, 1402-1408. [CrossRef] [PubMed]

65. Freund-Levi, Y.; Basun, H.; Cederholm, T.; Faxén-Irving, G.; Garlind, A.; Grut, M.; Vedin, I.; Palmblad, J.; Wahlund, L.-O.; Eriksdotter-Jönhagen, M. Omega-3 Supplementation in Mild to Moderate Alzheimer's Disease: Effects on Neuropsychiatric Symptoms. Int. J. Geriatr. Psychiatry 2008, 23, 161-169. [CrossRef] [PubMed] 
66. Chiu, C.-C.; Su, K.-P.; Cheng, T.-C.; Liu, H.-C.; Chang, C.-J.; Dewey, M.E.; Stewart, R.; Huang, S.-Y. The Effects of Omega-3 Fatty Acids Monotherapy in Alzheimer's Disease and Mild Cognitive Impairment: A Preliminary Randomized Double-Blind Placebo-Controlled Study. Prog. Neuropsychopharmacol. Biol. Psychiatry 2008, 32, 1538-1544. [CrossRef] [PubMed]

67. Quinn, J.F.; Raman, R.; Thomas, R.G.; Yurko-Mauro, K.; Nelson, E.B.; Van Dyck, C.; Galvin, J.E.; Emond, J.; Jack, C.R.; Weiner, M.; et al. Docosahexaenoic Acid Supplementation and Cognitive Decline in Alzheimer Disease: A Randomized Trial. JAMA 2010, 304, 1903-1911. [CrossRef] [PubMed]

68. Scheltens, P.; Kamphuis, P.J.G.H.; Verhey, F.R.J.; Olde Rikkert, M.G.M.; Wurtman, R.J.; Wilkinson, D.; Twisk, J.W.R.; Kurz, A. Efficacy of a Medical Food in Mild Alzheimer's Disease: A Randomized, Controlled Trial. Alzheimers Dement. J. Alzheimers Assoc. 2010, 6. [CrossRef] [PubMed]

69. Kamphuis, P.J.G.H.; Verhey, F.R.J.; Olde Rikkert, M.G.M.; Twisk, J.W.R.; Swinkels, S.H.N.; Scheltens, P. Efficacy of a Medical Food on Cognition in Alzheimer's Disease: Results from Secondary Analyses of a Randomized, Controlled Trial. J. Nutr. Health Aging 2011, 15, 720-724. [CrossRef]

70. Scheltens, P.; Twisk, J.W.R.; Blesa, R.; Scarpini, E.; von Arnim, C.A.F.; Bongers, A.; Harrison, J.; Swinkels, S.H.N.; Stam, C.J.; de Waal, H.; et al. Efficacy of Souvenaid in Mild Alzheimer's Disease: Results from a Randomized, Controlled Trial. J. Alzheimers Dis. 2012, 31, 225-236. [CrossRef]

71. Shah, R.C.; Kamphuis, P.J.; Leurgans, S.; Swinkels, S.H.; Sadowsky, C.H.; Bongers, A.; Rappaport, S.A.; Quinn, J.F.; Wieggers, R.L.; Scheltens, P.; et al. The S-Connect Study: Results from a Randomized, Controlled Trial of Souvenaid in Mild-to-Moderate Alzheimer's Disease. Alzheimers Res. 2013, 5. [CrossRef]

72. Faxén-Irving, G.; Freund-Levi, Y.; Eriksdotter-Jönhagen, M.; Basun, H.; Hjorth, E.; Palmblad, J.; Vedin, I.; Cederholm, T.; Wahlund, L.-O. Effects on Transthyretin in Plasma and Cerebrospinal Fluid by DHA-Rich n 3 Fatty Acid Supplementation in Patients with Alzheimer's Disease: The OmegAD Study. J. Alzheimers Dis. 2013, 36, 1-6. [CrossRef] [PubMed]

73. Shinto, L.; Quinn, J.; Montine, T.; Dodge, H.H.; Woodward, W.; Baldauf-Wagner, S.; Waichunas, D.; Bumgarner, L.; Bourdette, D.; Silbert, L.; et al. A Randomized Placebo-Controlled Pilot Trial of Omega-3 Fatty Acids and Alpha Lipoic Acid in Alzheimer's Disease. J. Alzheimers Dis. 2014, 38, 111-120. [CrossRef] [PubMed]

74. De Waal, H.; Stam, C.J.; Lansbergen, M.M.; Wieggers, R.L.; Kamphuis, P.J.G.H.; Scheltens, P.; Maestú, F.; van Straaten, E.C.W. The Effect of Souvenaid on Functional Brain Network Organisation in Patients with Mild Alzheimer's Disease: A Randomised Controlled Study. PLoS ONE 2014, 9. [CrossRef] [PubMed]

75. Phillips, M.A.; Childs, C.E.; Calder, P.C.; Rogers, P.J. No Effect of Omega-3 Fatty Acid Supplementation on Cognition and Mood in Individuals with Cognitive Impairment and Probable Alzheimer's Disease: A Randomised Controlled Trial. Int. J. Mol. Sci. 2015, 16, 24600-24613. [CrossRef] [PubMed]

76. Eriksdotter, M.; Vedin, I.; Falahati, F.; Freund-Levi, Y.; Hjorth, E.; Faxen-Irving, G.; Wahlund, L.-O.; Schultzberg, M.; Basun, H.; Cederholm, T.; et al. Plasma Fatty Acid Profiles in Relation to Cognition and Gender in Alzheimer's Disease Patients During Oral Omega-3 Fatty Acid Supplementation: The OmegAD Study. J. Alzheimers Dis. 2015, 48, 805-812. [CrossRef] [PubMed]

77. Wang, X.; Hjorth, E.; Vedin, I.; Eriksdotter, M.; Freund-Levi, Y.; Wahlund, L.-O.; Cederholm, T.; Palmblad, J.; Schultzberg, M. Effects of N-3 FA Supplementation on the Release of Proresolving Lipid Mediators by Blood Mononuclear Cells: The OmegAD Study. J. Lipid Res. 2015, 56, 674-681. [CrossRef] [PubMed]

78. Olde Rikkert, M.G.M.; Verhey, F.R.; Blesa, R.; von Arnim, C.A.F.; Bongers, A.; Harrison, J.; Sijben, J.; Scarpini, E.; Vandewoude, M.F.J.; Vellas, B.; et al. Tolerability and Safety of Souvenaid in Patients with Mild Alzheimer's Disease: Results of Multi-Center, 24-Week, Open-Label Extension Study. J. Alzheimers Dis. 2015, 44, 471-480. [CrossRef]

79. Jernerén, F.; Cederholm, T.; Refsum, H.; Smith, A.D.; Turner, C.; Palmblad, J.; Eriksdotter, M.; Hjorth, E.; Faxen-Irving, G.; Wahlund, L.-O.; et al. Homocysteine Status Modifies the Treatment Effect of Omega-3 Fatty Acids on Cognition in a Randomized Clinical Trial in Mild to Moderate Alzheimer's Disease: The OmegAD Study. J. Alzheimers Dis. 2019, 69, 189-197. [CrossRef] 
80. Freund Levi, Y.; Vedin, I.; Cederholm, T.; Basun, H.; Faxén Irving, G.; Eriksdotter, M.; Hjorth, E.; Schultzberg, M.; Vessby, B.; Wahlund, L.-O.; et al. Transfer of Omega-3 Fatty Acids across the Blood-Brain Barrier after Dietary Supplementation with a Docosahexaenoic Acid-Rich Omega-3 Fatty Acid Preparation in Patients with Alzheimer's Disease: The OmegAD Study. J. Intern. Med. 2014, 275, 428-436. [CrossRef]

81. Cummings, J.; Scheltens, P.; McKeith, I.; Blesa, R.; Harrison, J.E.; Bertolucci, P.H.F.; Rockwood, K.; Wilkinson, D.; Wijker, W.; Bennett, D.A.; et al. Effect Size Analyses of Souvenaid in Patients with Alzheimer's Disease. J. Alzheimers Dis. 2017, 55, 1131-1139. [CrossRef]

C 2019 by the authors. Licensee MDPI, Basel, Switzerland. This article is an open access article distributed under the terms and conditions of the Creative Commons Attribution (CC BY) license (http://creativecommons.org/licenses/by/4.0/). 